\title{
The Social Background of Witchcraft Accusations in Early Modern Debrecen and Bihar County
}

\author{
Ildikó Sz. Kristóf
}

The present study is the translation of an abbreviated version of Chap. 5 of my book entitled "Ördögi mesterséget nem cselekedtem." A boszorkányüldözés társadalmi és kulturális háttere a kora újkori Debrecenben és Bihar vármegyében ("I have not done any diabolic deeds." The Social and Cultural Foundation of Witch-hunting in Early Modern Debrecen and Bihar County) published in Debrecen in 1998.

The book examines the witch-hunting in Bihar county and its largest city in Eastern Hungary between 1575 and 1766. During this period altogether 217 trials were conducted against 303 accused, and my study aimed at detecting the social context of the accusations and the underlying beliefs. The working hypothesis was based on that now classical observation of social anthropology, according to which the charges of witchcraft resulted from the deteriorations of everyday human relations and so could allude to the existing conflicts of certain individuals

\section{I.S. Kristóf $(\square)$}

Hungarian Academy of Sciences, Budapest, Hungary

e-mail: ildiko.szkristof@gmail.com

(C) The Author(s) 2017

G. Klaniczay and É. Pócs (eds.), Witchcraft and Demonology in Hungary and Transylvania, Palgrave Historical Studies in Witchcraft and Magic, DOI 10.1007/978-3-319-54756-5_2 
or groups in communities. The two central questions of the examination were as follows: how (in what legal, religious and social context) and why (among what kind of social circumstances and with what motivations) were people accused of witchcraft in 45 Hungarian Calvinist towns and villages? To answer these questions, I have made use of a variety of archival materials. Apart from the documents of witchcraft trials themselves I have surveyed the Calvinist treatises published in early modern Debrecen, and also legal and medical documents. I could identify the protagonists of the trials through archival files such as town records, criminal and civic documents, censuses, documents belonging to the guild of the barber-surgeons, and the records of the Calvinist diocese. The first three chapters of my book discuss the ways of witchcraft accusations. The witch-hunts in Bihar county were of rather small size (1-3 accused per annum) and intensity (only $32 \%$ of the trials concluded in death sentence altogether) compared with the Western European witch craze. I have found that a possible explanation for this relative mildness of the persecution could be provided by a complex consideration of legal, religious, and other local social circumstances. Next to the peculiarities of the accusatorial system of investigation (as opposed to most of Western Europe, this system still existed in parts in early modern Hungary), Hungarian Calvinist demonology remained skeptical about the concepts of diabolic witchcraft common in hysterical Sabbathmythologies. Consequently, the judges of Debrecen and Bihar county were not urged to identify the accused persons as representatives of a sect directly associating with the devil. Moreover, the early modern history of the region was burdened with almost constant wars and skirmishes (the area belonged to the frontiers with the Turkish Empire), so the Christian communities living here seem to have been preoccupied with the need for mere survival.

Chapter 5 examines the concrete social circumstances of why people were nonetheless brought to witch trials in this region. Various legal, religious, social anthropological and socio-historical aspects could be brought forth to provide an explanation. As for the legal context, early modern Hungarian law obliged the secular courts to persecute witches. Calvinist demonology, although it regarded the worldly interventions of the devil as being of limited scope, urged the expurgation of various forms of sorcery and magic. Suspicion fell primarily on the practitioners of benevolent magic (e.g. popular healers, midwives, diviners, and the like) supposing that they opposed the ways of divine providence. Such 
official, religious and 'intellectual' considerations often coincided with contemporary folk beliefs in which witchcraft played an important role. The popular explanations of misfortune that turned finally into witchcraft accusations derived most often from dense everyday conflicts ('honest citizens' versus 'deviants', landlords versus tenants, burghers versus beggars, locals versus strangers, healers and midwives versus their clients as well as guilds, gentry versus serfs). My book suggests that witchcraft accusations indicated acute tensions in the communities concerned: the institutionalization of medicine and social care in the city of Debrecen and the rearrangement of privileges among the local gentry in Bihar county.

Considering that 18 years have passed since the publication of this work, it would have been useless to attempt to update the text with the scholarly literature that has come out since then. I decided to leave it as such representing an important period in Hungarian socio-cultural history, namely the late 1980s-early 1990s. Coinciding with the political changes in East-Central Europe, this period saw the emergence of historical anthropology in Hungary, mediated by, among others, English, French and German studies of witchcraft and witch-hunting. Chapter 5 of my book represents a basically socio-functional approach to the latter, but it evokes the emerging 'postmodern' i.e. narrational criticism as well that could be turned against it in several points.

\section{Witchcraft Charges and Their Local Social World}

Looking for social tensions within a community and for conflicts between individual people to explain the background to the accusations of witchcraft, and the consideration of witchcraft beliefs as a particular, anthropocentric explanation of unfortunate events is an approach rooted in the social anthropology of the Interwar period and after the Second World War. In the 1930s, E.E. Evans-Pritchard, in his works on the worldview of the Sudanese Azande people, interpreted witchcraft as a coherent system of concepts explaining the world which provided exhaustive answers to some very specific questions raised by the indigenous people, such as "Why did the misfortune happen to me?", "Why here?" and "Why now?"

However, as Mary Douglas pointed out in her 1970 overview, those British anthropologists following in the footsteps of Evans-Pritchard and claiming to adopt the functionalist approach (which lived its heyday in 
the 1940 and 1950s), merely borrowed and applied certain elements of their predecessor's conceptual scheme in their works about the belief in witches of different African peoples. Overall, as Mary Douglas underlines in her critique, it was not sociologies of knowledge that they wrote about, but the narrow analyses of varying depth of the social function of witchcraft - in the words of Max Marwick, of its role as a social strain gauge. ${ }^{2}$ These studies were also justly criticized in the 1960s, for instance by Victor Turner, for not taking into consideration the potential transformations of a society, and for presuming that lying in the background of witchcraft accusations are societies which 'reproduce' themselves in an unchanged form. ${ }^{3}$

Two British historians, Keith Thomas ${ }^{4}$ and Alan Macfarlane, ${ }^{5}$ who in the 1970s were pioneers in applying anthropological methods based on the many-sided analysis of the relations and conflicts between witch and victim to the examination of history of witchcraft in England in the sixteenth and seventeenth century, tried their best to avoid these traps. Since the widespread continental 'Sabbath myth', which generated massive witch-hunts, was more or less absent in England, they both saw witch-hunting in England as a distinct type where local witchcraft accusations were above all maleficium; that is, bewitchment cases resulted from some kind of everyday, realistic conflict between a witch and her victim. As they have established, the most common quarrels related in witness testimonies were ones in which the victim had refused some kind of request made by the witch. Keith Thomas proposed an interpretation, according to which these cases were possibly either violations of the institution of traditional neighborly assistance, or the absence of traditional support given to social groups living off the donations of others, poor people whose situation was uncertain — and in Elizabethan England, still unregulated. Alan Macfarlane-taking Thomas's idea one step furthercame to the conclusion that the witchcraft accusations of Essex in the sixteenth and seventeenth century had stemmed from the break-up of norms of coexistence founded upon the tradition of mutual assistance, and from the birth and gradual expansion of an individualistic, new system of values, in the line of the 'spirit' of capitalism. Thus, in searching for the function of witchcraft accusations, the two researchers were able to highlight changing social norms. Several researchers followed the methodology of Thomas and Macfarlane, which was to analyze the social conflicts of the witch and of the victim and the conflicts as related in the witch trials. William Monter studied witch trials from this perspective 
in Switzerland, as did Erik Midelfort in Southwest Germany and John Putnam Demos in New England. ${ }^{6}$

Meanwhile, a recent psycho-anthropological study raised a significant challenge concerning the research of conflicts mentioned in witness testimonies. The French researcher Jeanne Favret-Saada discovered during her field-work conducted in the Bocage in the 1970s that the accounts of conflicts narrated by the villagers who considered themselves victims of bewitchment did not necessarily reveal the confrontation that actually took place. This grain of truth could be unrecognizably transformed and distorted into a kind of traditional model of witchcraft narrative, depending on how much the narrators altered and adjusted their stories in order to meet the expectations of their community. ${ }^{7}$

The question arises as to whether the conflicts appearing in the witness testimonies of witch trials - such as the refusal of a favor noted by Keith Thomas and Alan Macfarlane-and the other elements of maleficium narratives are rather the stereotypes of a specific type of narrative, and not the reflections of actual events. Obviously it is impossible to give an answer to this question merely by working with maleficium narratives documented two or three hundred years ago. As we will indeed see below, several essential motifs of witchcraft accusation cannot be elicited from those documents. Their analysis, nevertheless, can tell us a lot about the frameworks within which the people of that time phrased their misfortunes.

Let us take a closer look at the conflicts as related both by the victims and those under the suspicion of being witches. The victims $(84.84 \%$ in Debrecen, $86.36 \%$ in Bihar County) usually identified themselves as offenders - that is, they had offended the witch, and the suspected witches as the offended (95.45 and $88.25 \%)$. The rest of the cases confirm the assertion of Jeanne Favret-Saada, claiming that witchcraft accusation could have resulted from conflicts between entire households. In certain cases, for instance, the offender might be a relative of the victim (9.09\% in Debrecen, $9.84 \%$ in the county), or the offended related to the witch $(9.84 \%$ in the county). The typical setup of an offender victim and an offended witch was relatively rarely reversed, according to the testimonies. We only encounter three cases of an offending witch in Debrecen, and two cases (or four, if we count the relatives as well) in the county as a whole.

Similar to the English witch trials studied by Keith Thomas and Alan Macfarlane, the most common conflict among the types of narratives 
from Debrecen and the villages of the county was the refusal of a request made by the witch. The most frequent requests from the victim by the person later suspected of having bewitched them were some kind of food (bread, dairy product, eggs), or meal (porridge, roast meat), or-primarily in the county-household appliances (pot, sieve, cauldron to cook brandy, weaving loom, laundry tub). Rarely money.

The fact, however, that the refusal of a request only occurred in $28.78 \%$ of the cases in both Debrecen and Bihar County suggests that the maleficium narratives extended the scope of witchcraft accusation to a much wider circle of social interactions. The second most common type of conflict-22.72\% in Debrecen and $14.77 \%$ in the countywas the violation of an agreement or arrangement by the victim. For instance, the victim did not require the healing services they had agreed upon with the other party, did not pay the fee due for the treatment, ousted the tenant of the house, carried out a commission (tailoring, sewing) either badly or not at all for someone, or did not pay the salary of someone working for them (ploughing, harvesting). The witchcraft narratives also mention other, physical abuses-16.01\% in Debrecen and $11.36 \%$ in the county. For instance, the eventual victim physically attacked the witch, or broke her pot or her sieve, broke her window, harmed or killed a cow belonging to her, hoed up her hemp, or vandalised the witch's land with their cart.

Leaving the above mentioned question of Jeanne Favret-Saada open for now, the question about how much the accounts of quarrels tell us about the actual reasons behind the animosity between the victim and the witch, and how much of it consisted rather of secondary explanations, projections of the victim's misfortune, let us examine closely some of the circumstances of these conflicts.

Certain disputes seem to be connected to a specific time or period. Such dangerous times were the turning points of life (birth, marriage, death), and other festive and community occasions. It is apparent that both in Debrecen and in the county these maleficium narratives, put in different contexts, still essentially tell two variants of the same story with an identical structure: the breaking of a norm and the punishment that follows. In one part of the cases, the victims were trying to prove that the witch had offended certain time-related communal rituals and expectations, and that they had warned and rebuked them for it. This warning then led to a quarrel, which eventually ended with the 'norm-breaking' witch's vengeance: bewitchment. In other narratives, the opposite 
situation can be found: it was the victims who seem to have offended a normative expectation, and the witch's bewitchment falls upon them as a punishment. The witch, in these cases, appears to be the guardian of these norms. Let us look at some examples.

According to the narratives, in cases related to childbirth and baptism the most common cause of conflict was that the victim did not ask the eventual bewitcher to be the midwife or the godparent. Witness testimonies also report several other types of conflict. According to the account of the 1693 trial of Mrs. János Molnár, a healer in Debrecen and the daughter of a local midwife, she had scolded a woman in confinement for not keeping the magical protective rules relating to the infant: "Why don't you breastfeed your child in a bonnet, because your child was fed during the night by the night people." The well-intentioned warning, however, turned against Mrs. Molnár, because when the child fell ill, they suspected her bewitchment to be the cause. ${ }^{8}$

The maleficium narratives also reveal a number of conflicts resulting from the violation of instructions and rules relating to the period leading up to a wedding. According to the 1723 trial of Mrs. István Szegedi, she was considered to be the reason for the death of a groom who died on his wedding night. The witnesses say that Mrs. Szegedi was invited to the betrothal, but she was not asked to come and visit the bride from Gáborján, and they did not bring her along when the bride was brought home. Another bride told the judges that Mrs. Szegedi had appeared before her during the night, because she had not chosen her son for a husband. Mrs. Szegedi had reproached the girl that she was disparaging her son: "Why didn't you marry my son, he has just as good clothes as the one you want to marry." ${ }^{9}$ From the 1715 trial of Mrs. István Szabó we learn that a groom from Kismarja believed his illness to be due to telling people about the magical procedure Mrs. Szabó had advised him to carry out for his wedding. ${ }^{10}$ István Lengyel, an itinerant fiddler, was hit by one of the victims because he had started to play when the priest was still among the wedding crowd. The death of this person was considered to be the vengeance of Lengyel, according to his trial in $1716 .^{11}$

The witnesses also mentioned conflicts related to funerary customs, namely to the organization and implementation of funeral feasts, which eventually led to witchcraft accusations. In the 1731 trial against Mrs. Márton Nagy and Mrs. Benedek Bálint from Hegyközpályi, one of the victims said that the reason Mrs. Nagy had bewitched her was that, when they were cooking for the funeral feast of a neighbor, she had left earlier 
than she was supposed to. At another feast, the cooks were quarrelling about who should serve the food. They did not let Mrs. Benedek Bálint, and therefore when one of the cooks became ill it was considered that Mrs. Bálint had bewitched her. ${ }^{12}$

The maleficium narratives also associated the conflicts resulting in witchcraft accusations with other feasts, holidays and social events.

Returning to the proposition of Jeanne Favret-Saada questioning the authenticity of maleficium narratives, I believe that the examined narratives themselves could hardly prove or disprove whether events related two or three hundred years ago bore any relation to the accounts related of them. It is more important to understand what they represent: a variously regulated form of social cohabitation, in which any kind of violation implied retribution including sanctions associated with the sphere of beliefs. In the narratives we encountered the character of both the 'norm-breaking witch' and the 'norm-breaking victim'. From the perspective of the logic of witchcraft accusations, the former testifies to the protection of norms: the person who violates certain rules of common life will be involved in witchcraft rumours, brought to trial and judged. Interestingly, however, the latter is legitimizing the transgression, and testifying to the change of norms: persons who violate certain common rules will be victims of bewitchment, but since they gain the opportunity to punish or have the bewitcher punished or sentenced, the behavior and the act of the norm-breaker is justified in the end. Although it is the latter case of maleficium narratives that are in the majority, and the offender-victim-offended-witch relation can be considered dominant, our analysis is still confined to the level of narratives. I would not go further than to assert that the victims of the period and the territory of our interest talked about certain norms regulating their social life as obligatory rules, which, nevertheless, could be modified or changed in the context of witchcraft.

It is apparent, however, that according to the maleficium narratives most of the conflicts triggering witchcraft accusations and which arose in the course of common social life and cooperation are not related to a specific time period. We can also discover in the background of the conflicts frequently occurring 'dangerous relations' which, according to historians and anthropologists (Keith Thomas, Alan Macfarlane, Max Marwick and others) studying the anthropology and the sociology of witchcraft accusations, can reflect vulnerable social relations. If these dangerous relations can be made to correspond to the social processes 
of the region, and more closely to the society of each community at the time, then-despite the narrative character of the maleficium narratives emphasized by Jeanne Favret-Saada-we can suspect existing social problems in the background of witchcraft accusations.

The trial documents, unfortunately, do not provide a full picture of the nature of relationships between victims and witches. Among the 171 victims in Debrecen there were only 64 people (37.42\%) who we know had some kind of familial relationship with the accused witch. This ratio is much worse in the county: among the 554 victims there were only 38 people $(6.85 \%)$ of whom we know more.

In the majority of the known cases, the victim and the witch were not related to one another. In Debrecen only $14.06 \%$ of the cases were between relatives. In the county this ratio is much higher, $(44.89 \%)$, but it is worth noting that the parties were not so much blood relatives as 'artificial' kin (primarily in-laws and godparents). The rest of the cases indicate some sort of spatial relationship. Among the latter we primarily find neighborly and lodger-landlord relations and, on a different level, we can count the relationship between magical specialists and patients in this category as well. It is obvious, however, that such a small amount of uncertain data accessible from the witch trials can tell us very little about the problematic sectors of the concerned communities, and the hypotheses formulated on the basis of such data are only very frail. Those victim-witch relations of which we know seem to suggest that from the late seventeenth century until the mid-eighteenth century kinship and spatiality played an equal role in witchcraft accusations in the smaller market towns of the county, while in Debrecen in the same period the latter case prevailed. The dangerous relations I consider to be the most characteristic (and the categories of which I will discuss below) were, nonetheless, mostly based on certain spatial relations.

\section{'People of Ill Repute’ and 'Honest Christians'}

Percent of the 303 accused witches in Bihar County, 27.06\% (82 people) were charged with committing other crimes-mostly sexual crimes (adultery, fornication, pandering, abortion, etc.) and theft. It is noteworthy that 62 of the 82 people came from a market town $(75.60 \%)$, and only 20 came from villages $(24.39 \%) .53$ were from Debrecen, which means that $41.73 \%$ of all the witches brought to trial were also charged with other accusations. 
Since we have no statistical studies at our disposal that would reflect the crime ratios of the time in Debrecen, the market towns or the villages, these data can only be interpreted within significant limits. The low $27.06 \%$ incidence rate of multiple crimes suggest that witchcraft was not necessarily associated with other offenses, and witchcraft accusations did not necessarily target 'persons of ill repute' (cégéres személyek). At the peak of witch-hunting in Debrecen, for instance, between 1690 and 1694-according to the statistics I have assembled on the basis of judicial records-200 people were punished for theft, 68 for fornication, 7 for profanity, and none of these were accused of witchcraft. Seen from the opposite angle, of the eleven witches brought to trial during this period not one was accused of any other crime.

There is agreement among several researchers that the persons accused of witchcraft cannot universally be considered as notorious criminals: this is the standpoint of the synthetic account of European witch-hunting written by Brian Patrick Levack, and some-as among them Robert Muchembled-even object to the use of the term 'deviant'. William Monter, when discussing Swiss witches accused of other crimes, talks about "negative personality types". ${ }^{13}$

The most common crimes associated with the accused witches in the region I have examined-sexual transgressions and theft and in Debrecen also profanity and blasphemy-were considered to be grave crimes by the Calvinist Church, thus defining the moral norms of the time, and so I believe that in this sense the 82 witches accused of multiple crimes could at the least have been regarded as 'persons of ill repute'. It is apparent that such people were to be found in a significantly greater ratio in urban settlements (around 75\%) than in villages (around 20\%). Even though there are very few comparative data at disposal, it still seems that other aspects reflect a similar village-town disparity. Among the accused witches from the Essex villages, for instance, only 15\% were accused of other crimes; meanwhile in the case of the urban settlements of New England this ratio is $36 \%$, and is even higher, $45 \%$, in the city of Lausanne, for example. ${ }^{14}$ It is possible that the difference in the crime rates between witches accused in urban and rural environments also indicates differences in urban and rural criminality, but to my knowledge this is an area yet to be studied. As regards the relation between the ratio of criminality of the accused witches to that of their community, so far only the studies of John Putnam Demos are available, according to which the ratio of criminality in the seventeenth century urban settlements of 
New England was somewhere around 10-20\%, while that of the accused witches, as I have previously mentioned, was much higher, around $36 \% .{ }^{15}$ Taking all this into consideration, Demos warns that whatever name we use, we have to find closer ties between witchcraft and other crimes than research has so far suggested.

These ties, which among the regions I have studied were especially evident in Debrecen, were probably strongly influenced by the witchcraft concepts of the Calvinist church. The Calvinist witch stereotype has a side-primarily emphasized in the treatise of the Puritan Mátyás Nógrádi ${ }^{16}$ - which associated the sin of witchcraft with other crimes. Contemporary Calvinist theology usually saw a connection between the various sins. They formed a chain, as György Komáromi Csipkés explained in 1666. If someone committed a crime, they were unlikely to escape others: "Although the source of every crime a man commits in his life is Original Sin ... often ... the committed crime is the cause and the source of subsequent crimes. It is easy to commit the next crime, as David passed from fornication to murder... If someone commits a crime, it entails many others, because a crime is like a chainlink." 17 The "nature of the crime in these actions" could be manifold, as Gáspár Decsi had listed almost a century earlier in his 1582 dissertation, "Adultery, fornication ... idolatry ... poisoning ... envy, wrath ... heresy, murder, drunkenness, riotousness". ${ }^{18}$ According to the Calvinist argument, by committing the first sin, one would forfeit the mercy of God, and in the absence of this further crimes would come easily. ${ }^{19}$ We can fairly presume that the Calvinist Church's concept of crime affected the way witchcraft accusations were oriented. If the communities-whether in New England or in Bihar County-appropriated this concept, witchcraft accusations could easily have been directed at people who previously, in their past, had done something of ill repute.

On the other hand, it is worth taking note which crimes were most often associated with witchcraft accusations. It seems that the transgressions that appeared most frequently in the accusations in Bihar County, such as sexual transgression, theft, vulgar discourse (threats), blasphemy, were also those most prevalent among the accused witches of other Calvinist regions (England, New England, Switzerland). ${ }^{20}$ It was again John Putnam Demos who drew attention to the fact that the nature of these transgressions might be somehow closely connected to the meaning of witchcraft. A bewitchment is the 'unfair'-because supernaturally aided-appropriation of something, be it men's potency, their ability to 
approach women, the milk of the cows, human health or even peaceful everyday communication. The same thing happened in cases of crimes most frequently associated with witchcraft: these were actions occurring in real life and considered 'unfair' and immoral. ${ }^{21}$

Lying in the background of opinions arguing a connection between witchcraft and other crimes (if it is not merely a reflection of the most common forms of deviancy in the given community, nor merely the influence of Calvinist theology's concept regarding the chain of sinspossibilities which, however, should not be fully dismissed) we could discover the association of the perceived supernatural appropriation with other ones and vice versa. The judicial court of Debrecen, for instance, affirmed in two cases that witchcraft and sexual transgressions were closely related. In an indictment from 1725 it was written that "according to common parlance whoring goes together with witchcraft", while a prosecutor's speech in front of the court in 1717 summarized the accusations against two women as follows: "in their youth they lived in fornication, whoring and pandering; in their old age they committed themselves to witchcraft, charms, binding and unbinding". ${ }^{22}$ Furthermore, we also have to point out that among the 82 witches subject to multiple accusations only nine were men, all residents of Debrecen. The others were married women, except for three girls. The indictment speeches and the testimonies of witnesses suggest that both the judges and the victims called the "witches" to account for rules and expectations related by contemporary society and the Calvinist Church to the role of married women and mothers.

In 1725, for instance, Mrs. Márton Rácz from Debrecen was accused (also) of leading a debauched lifestyle. In her indictment one can read: "in her house, she is not vigilant like a sober, God-fearing woman, but she gets drunk and indulges herself [in earthly pleasures], to the consternation of her God-fearing Christian neighbors." 23 In her 1724 trial, "Old" Mrs. András Nagy from Kóly was brought to account for missing church. The witnesses, asserting that she did not visit the house of God, cited something she had said about herself: "I am a damned soul". ${ }^{24}$ According to people who knew her, Mrs. Miklós Kulcsár from Helyközpályi violated the interdiction of Sunday labour. Testifying against her in her trial in 1715, one of her neighbors said, "they always churned the cream on Sundays...to make butter." 25 Several women who were thought to be witches were described by witnesses as having an ugly, quarrelsome tongue. Mrs. István Oláh from Hegyközpályi, we 
find from her trial in 1731, "lifted her shirt off her buttocks, and asked the witness to lick her behind" ${ }^{26}$ Mrs. Miklós Kulcsár threatened one of her victims, saying she would "lash him with her tongue like a Gypsy woman". ${ }^{27}$

Again, we have to return to the question of Jeanne Favret-Saada: were these women actually as the witnesses described them in the witchcraft trial, or are these descriptions only to be interpreted in the context of maleficium narratives? Based on the few cases in which I was able to complement the documents of witchcraft trials with other sources (such as demographic censuses, judicial documents of other civil and criminal proceedings, etc.) and examine the micro-context of accusations, my answer to this question is neither a firm yes nor a no. There were indeed several women whose pasts revealed previous legal proceedings, which confirmed other accusations beside that of witchcraft; in certain cases, however, we can see that the distinction between a 'person of ill repute' and a 'God-fearing pious woman' was very much dependant on the composition of the neighborhood, their micro-community. Let us look at a few examples.

When in 1701 the court sentenced Mrs. István Kis to be beheaded (the usual punishment for adultery), they referred to her "long-time inappropriate behavior". Mrs. István Kis was a middle-aged, married woman. I do not know the occupation of her husband, but she was known as a healer, with patients visiting her from as far away as Szovát. According to the testimony of one woman, Mrs. Kis healed the injured hands and feet of her husband: "she pierced the blisters on his foot, and she also gave grease in a nutshell for his hand, which healed him." Mrs. Kis herself spread the perception, according to which she had been haunted and tortured by witches for healing their victims. According to one of the witnesses "they asked [Mrs. Kis] why her hands were injured. She replied that Mrs. Sóder, the pagan soul, came in through the window with her company and with a knife, and she had cut her." 28

Her "long-time inappropriate behavior" is confirmed by two other legal cases prior to her witch trial. In September 1694 she initiated slander proceedings against her mother-in-law, who had spread a rumour about her that she was "caught with a lad" in Elep by some soldiers, who made her pay 12 Forints in exchange for their silence. The mother-inlaw was able to prove the truth of what she claimed and Mrs. István Kis was punished. ${ }^{29}$ Besides her licentious lifestyle she seems to have been quite a gossip, as turns out from her second trial in April 1695. This time 
she was punished with 'tongue tying' (emenda linguae) because she had spread a rumour about a young couple that neither the husband's nor the wife's past was immaculate. By the time Mrs. Kis was in front of the judges for witchcraft, she already had the reputation of being a loose and loudmouthed woman. Several witnesses confirmed this in their testimonies at her trial. They said she liked to narrate other people's bedroom secrets, or initiate various procedures for bringing together young couples through love magic: "she said...that a woman named Pila Bán got involved with a young man who didn't want to marry her, so she burned his belt, and thus he had to marry her." Before the son of János Kenyeres got married "she heated up a horseshoe and dug up the footsteps of the girl with it, also cooking her underwear in wine, and had the boy drink it, so that he would fall in love with her." It is very likely that no oneespecially not the newlyweds and their relatives-appreciated the airing of their pasts and of the stories of how they became a couple; and especially not by a woman who had already been punished for adultery and who had since continued to live in vice. The witch trial of Mrs. Kis also reveals that she had recently had as a lover a young lad named Domokos, and the woman boasted about how he was going to marry her after her husband died. He gave her a skirt and a cloak, and they were also caught together in a courtyard. All this, however, did not stop Mrs. Kis from having other young men over to her house, and "to taste the wine at the house of the judge." It appears that her relationship with Domokos had been quite turbulent; they fought frequently and the lad occasionally beat her up. Before the trial, however, Domokos had had enough of Mrs. Kis. He wanted to leave her, but, as witnesses told, the woman went after him crying.

The maleficium narratives related to Mrs. István Kis are intertwined with other accusations against her; earlier conflicts told by the victims primarily involved sexual transgressions and drunkenness. The narratives associated the witchcraft of Mrs. Kis with her 'ill-reputed' lifestyle.

The trial did not reveal whether Mrs. Kis was indeed a friend of the judge, or if she only bragged about it. When one night, however, she appeared again at the house of her former lover Domokos, drunk and crying, the judge had her arrested. We can presume that her associate, seeing that her previous two punishments had not changed her lifestyle and that her gossiping was still endangering the good reputation of her acquaintances, and that due to her scandalous life she jeopardized the ideal of the "God-fearing pious woman", saw no other solution 
than to resort to the use of witchcraft accusation in order to get rid of her once and for all. Finally, the court sentenced her to be beheaded for her 'witchcraft' and "especially... for her obvious fornication and drunkenness". 30

The case of Mrs. Márton Rácz from Debrecen illustrates well how the perspective of the stereotypical witch-victim relations of the maleficium narratives changes if we get the chance to look behind the narratives. Mrs. Rácz's witch trial was in the spring of 1725. Márton Rácz and his wife moved to Debrecen from Sámson. I was not able to determine exactly when this happened: in 1722, however, they were already living there. Rácz was a wealthy butcher; he also bred sheep. He employed his own shepherd, and also merchandized milk. They hosted four or five lodgers in their house in Péterfia street in the third district (tized $\left.{ }^{31}\right)$. As we can deduce on the basis of the censuses, the conflicts leading to the witch trial were limited to a very small area: from the 59 witnesses testifying against Mrs. Rácz, 36 were certainly residents of the same street, and 21 lived in the near vicinity in the third district. Mrs. Márton Rácz was described by the witnesses as a "fair-haired, fat, red woman" in her middle age or a little older (not too old to keep lovers). Her adult son had already moved out from the parents' house to that of a neighbor, the widow of Mr. Ormányközi, also in the third district.

When in January 1725 the house of Mrs. Ormányközi burst into flames a storm of animosities related to Mrs. Rácz surfaced. Mrs. Rácz and her son hurried to help put out the fire, but at the scene one of their neighbors, János Petermány from the third district, attacked them with an axe, calling Mrs. Márton Rácz a "witch whore", and wanted to chase them from the site. Petermány was a bacon butcher, who must have had some kind of professional conflict with the family of the butcher Rácz. According to his testimony, earlier Mrs. Rácz "had gone to his house and started to curse with various insults, telling him what she would do to his mother; she cursed not only him, but his entire household." Although Petermány did not elaborate on how he believed Mrs. Rácz had bewitched them, the 1728 census revealed that his wife was suffering of some sort of (mental?) illness; she was "harmed".

Mrs. Ormányközi probably sold her house to the Rácz family in exchange for their son's care for her until she died-as an early modern equivalent of a care and maintenance contract. The relationship of the cohabiting 'caregiver' and the 'dependent' went sour: as the witch trial revealed: the widow attributed the death of her husband and her various 
other health problems (the sores on her face and her weight loss) to Mrs. Rácz.

In the first days of February 1725 Mrs. Márton Rácz started a slander suit against János Petermány, but by February 9, the volume of incriminating testimonies gathered against her was so vast that she became the subject of accusation. It is quite revealing that most of the victims were from her street, 18 people were of her immediate neighborhood, the third district. Seven victims came from the second district, 15 from the fourth, four from the first and only two people from the fifth district.

According to the witnesses the "fair-haired, fat, red" Mrs. Márton Rácz was far from the ideal of a "God-fearing honest woman". One of the witnesses, a neighbor from the fourth district, Mrs. András Nagy, had known the Rácz family for a long time. She used to stay at their home when they lived in Sámson and she was visiting the local healer with her husband. As Mrs. Nagy told in front of the court, Mrs. Rácz had just left her husband "to run away with a man next to the Szamos river". The county court (sedria) punished her for this crime, but her husband eventually took her back. It is not impossible that the reason for moving from Sámson was to avoid the village gossip. Mrs. András Nagy obviously did not keep the information she had acquired in Sámson to herself; when the Rácz family moved to Debrecen she shared the past of the woman with the whole street.

Mrs. Rácz seems to have continued her licentious lifestyle in Debrecen: in her witch trial, 20 of her close neighbors from the third district, five from the second, and four of the first district talked about her frequent drunkenness, her recurrent adulteries and blasphemies; two residents of the fourth district accused her of theft; and one of her neighbors from the fifth district witnessed when she got into a fight with her husband. Mrs. Rácz, when her husband went off to deal with his sheep or on a merchant trip, often had wine brought to her house or went to visit neighbors. Sámuel Erdélyi, a weaver from the third district, said, "he knows about her frequent drunkenness, and the debaucheries at her house, they often had a loud rumpus at her house, one could even hear the noise across the street." János Gömöri, a bootmaker and district official of the fifth district, also testified to her "drunkenness and cursing by calling the others roguish souls and dog spirited"; he even saw her "fighting". Márton Rácz himself complained to their neighbors about the behavior of his wife. According to Mrs. János Szappanos, a widow and petty merchant in the third district, he explicitly said, as he 
pointed at his mortar: "Oh my, dear neighbor... if this mortar could talk, it would tell stories about my wife: the other night I had to kick a young man off her belly [...] [Márton Rácz] tore his cloak off his neck with a pitchfork."

The maleficium narratives given in relation to Mrs. Rácz-just as in the case of the above mentioned Mrs. István Kis-correspond to the woman's lifestyle 'of ill repute'. The victims in court typically mentioned incidents relating to the context of eating and drinking and visiting neighbors: she gave a "bad" beverage (wine, brandy) to the victim, or gave "bad" food to the guests, who attributed their subsequent health troubles to the accused. Her husband had the same opinion of her; he complained to several of his neighbors about an incident in Sámson, when his wife "gave him a beverage after which he would have died, if he had not drunk water ... he vomited blood afterwards." The waitress of the street's tavern, Mrs. György Beke was convinced that her leg was impaired because she refused to give credit on wine to Mrs. Rácz.

If we take a closer look at the people who claimed to be victims of Mrs. Rácz, we can clearly see in several cases that they had their share of troubles (poverty, misery, old age, illness) which they could 'project onto' and blame on the witch figure embodied by Mrs. Rácz. Using the 1730 census conducted in Péterfia street, among the neighbors testifying against Mrs. Márton Rácz we found 20 guild craftsmen, 11 tradesmen, nine farmers, and 12 landless inhabitants who mostly worked as hired labour, living in ordinary houses or earth huts or cottages. Most of them did not come from the poorest stratum, but not the wealthiest either. It seems, however, that none of them was close to the level of the Rácz family: we have thus a case of accusation from below.

Furthermore, it is also noteworthy to observe that many of the victims had to overcome their own personal tragedies. The census takers often noted that the relative of the person in question was ill, old, widowed or impoverished and destitute. Let us look at a few examples. I have already mentioned the "harmed" wife of János Petermány, the bacon butcher from the third district. The third-district weaver Sámuel Erdélyi, who survived from his profession, had only a "shanty", with only a half bowshot ${ }^{32}$ of land and vineyard, and only one cow and one pig. Mrs. György Némethi, also of the third district, whose reason for calling Mrs. Rácz a witch we ignore, was a wife of a smith who was stated as being old: they lived in a "withered" house with two bowshots of land. Mrs. János Ürmös, the wife of a button-maker (third district) lived 
in a "hut", with a half bowshot of land, and one bowshot of vineyard and one cow. János Varga Szabó (also third district), who attributed the death of his first wife to bewitchment by Mrs. Rácz, and was an unspecified craftsman, lived in a "withered" house with a half bowshot of land. The widow of János Zagyva and her son (third district) were farmers and lived in a "hut" with one bowshot of land and a "sickly" cow. Mihály Varga, who also lived in the street (first district) "used to trade cattle" but he had become "impoverished" and was left with only one and a half bowshots of land and three "bad" horses. Mrs. András Gyarmati, the widow of a cobbler (third district) lived in a "hut" "with his poor orphans", owning also just a half bowshot of land and two "bad" horses. Mihály Czégény was a "sickly" market tailor (fourth district) living off of one cow. Mrs. István Katona (second district) had no land, only a "bad house" and three mill horses. The widow of István Szabó (third district) the lodger of another widow, Mrs. János Szappanos, was according to the census an old woman "selling offal". The widow of János Balogh (third district), who attributed the death of her husband to the bewitchment of Mrs. Rácz, became a lodger: "she sold her house and lived off the money". Mrs. Mihály Szücs (fourth district), who allegedly became sick from the wine of Mrs. Rácz, whose "body was sucked" and who also blamed Mrs. Rácz for having stolen five taler from her, also had no land and lived in a "bad hut" and had three mill horses. János Agárdi (second district), who suspected Mrs. Rácz of causing the illness of his wife, was a livestock-farmer living in a "withered" owning one bowshot of land and "30 wasted sheep". The widow of István Harsányi (third district), who had caught Mrs. Rácz with her shepherd and then became ill, worked on her one bowshot of land and owned two "bad" horses and a "small house". After the death of her husband, according to the census, "she provided food for her three schoolchildren herself". Mrs. Mihály Veres (second district), who was also "poisoned" when given a bad beverage by Mrs. Rácz, was a smallholder with only a half bowshot of land, living in their "shabby house" with her husband, and they were "left with only one bad horse, the others died." She tried to improve their living conditions by "baking fried cake (csöröge)". Her mother, Mrs. János Darabos (fifth district) was an old merchant living in a "hut". ${ }^{33}$

Four former lodgers of the Rácz family also claimed that she was a witch after they had been kicked out of the house; it is also noteworthy that Mrs. Rácz's lame son also considered his handicap to be a result of his mother's bewitchment. 
Based on the image we get of the victims, we can reasonably presume that when in the maleficium narratives these men and women talk about becoming ill because of the food and drinks Mrs. Márton Rácz had given them, or after having caught her cheating on her husband, they were actually reflecting-hidden behind the stereotypes of witchcraft-a specific situation of social cohabitation of the age, overloaded with multiple tensions, which triggered a vast number of conflicts. The situation, namely, of what it meant when a wealthy, lively, foulmouthed, andaccording to the beauty standards of the age - pretty "fair-haired, fat, red woman", arrived in a mostly modest neighborhood-among the members of which many had suffered or were heading toward bankruptcy, and several were sick, old, widowed-who led a lavish lifestyle, and who "told people what she would do to their mothers just like men do", and who, to cap it all, was not even a local. The neighborhood, living under difficult conditions, already struck by various disasters and probably jealous in many aspects, found an appropriate scapegoat in the financially superior and morally 'inferior' woman who was so different from them, and simply excluded her from the community.

After establishing that she was a witch, the court banished Mrs. Márton Rácz from the city and ordered the demolition of her house in May $1725 .^{34}$

The witchcraft accusation in the cases of the above described witches "of ill repute" had a function similar to that of one of the groups of maleficium narratives related to the dangerous times discussed earlier: it protected the norms sanctioned by the community and the Calvinist Church: in this case the expectations related to the behavior of a "Godfearing Christian woman", and it served the reinforcement and the transmission of these norms.

However, the witchcraft narratives told about the accused persons "of ill repute" did not necessarily describe conflicts stemming from such norm-breaking behavior; witchcraft accusation also did not necessarily target the 'deviants' of the community. As the few detailed examples of accused witches confirm, maleficium narratives often withheld current or past conflicts and oppositions on the grounds of which some people could become witches, while others victims.

The most important reason why it is necessary for researchers to make an attempt to look behind the narrated conflicts, to delineate the most features possible of the environment and of the past of the accused, is that these conflicts and oppositions were apparently far from being due 
to a single dangerous relation. Besides, the "ill-reputed"- "God-fearing, honest Christian" opposition was coupled with other oppositions: in the case of Mrs. István Kis it was healer-patient; in Mrs. István Horváth's it was neighbor-neighbor and lodger-landlord opposition; and in the case of Mrs. Márton Rácz it was the oppositions of poor neighbor-rich neighbor, caregiver-dependent, lodger-landlord, mother-son, health-illness, etc., all of which resulted in very complex conflict situations.

In terms of the targets of witchcraft accusation, we can see that the type of dangerous relationship I have referred to was only one among many others.

\section{Healers, Midwives and Their Social Environment}

Among those accused at the witch trials I have examined, there were in total 45 healers and 13 midwives. This second type of dangerous relationship was primarily characteristic of Debrecen: $30.70 \%$ (t39 people) of the accused practiced healing and six women (4.72\%) were midwives. Among the accused in Bihar County I only found six healers $(3.40 \%)$ and seven midwives $(3.97 \%)$. The ratio of the healing narratives (stories about the treatment of various illnesses considered to be bewitchments) reflects a similar disparity: in Debrecen accounts were given of 129 cases of healing, eight more than there were maleficium narratives, while in the county trials only six cases of healing were mentioned. There are specific social reasons for this city-county difference.

The phenomenon where a considerable part of the people accused of witchcraft were representatives of benevolent magic, of popular medicine and of the profession of midwifery is not unknown in international and Hungarian research. Keith Thomas and Alan Macfarlane considered this phenomenon one of the characteristics of witch-hunting in England. According to Keith Thomas, the accusation of witchcraft seemed more credible if it was directed against people considered to be experts in some kind of magical knowledge (such as positive magic). ${ }^{35}$ Richard Horsley, meanwhile, has shown that this is far from being particular to England; in continental witch trials-from Lorraine to Austria, from Luzern to Schleswig-Holstein-the practitioners of positive magic were just as much, or even more objects of witchcraft accusations before the court. ${ }^{36}$ In addition to the fact that demonological literature considered the practices of popular healers and midwives diabolical and incited their persecution, the experts of "white" magic themselves also issued 
witchcraft accusations, in many cases with the aim of eliminating a rival magical specialist. ${ }^{37}$

Ferenc Schram, an expert on Hungarian witch trials, has drawn the attention to the fact that the number of representatives of popular medicine was very high among the accused witches; most recently Ágnes R. Varkonyi has pointed out that "in the background of certain trials one can observe the rivalry between healers". She also presumed that Hungarian witch trials came to an end due to the establishment of a centralized network of public healthcare in the eighteenth century and to the effect of the medical and healthcare education of the age. ${ }^{38}$

In the analysis of the witch trials of Bihar County I have considered these aspects as well. Dangerous relations between healers and midwives appear to have been manifold. They reflected not only the tensions between these specialists of magic and their patients (only intensified by the fact that the patients spread the evil fame by denouncing the unsuccessful healer as a witch when turning to another specialist), but also the strong competition between healer and healer, midwife and midwife (who also brought one another into disrepute by claiming that their competitors were witches), and the dichotomy between 'legitimate' and 'illegitimate' healing and midwifery. Besides the tendency in Calvinist demonology to denigrate benevolent magical activities and the fact that these activities were also customarily associated with witchcraft in popular belief, one can often discern well-perceptible social processes behind the conflicts relating to healers and midwives.

The accusation according to which the suspect had been practicing some kind of unusual, improper healing activity (usually considered 'illegitimate'), was often brought up throughout the entire period of our enquiry-primarily in the witch trials of Debrecen.

A woman named Erzsébet was accused of performing "evil" healing and "male medicatio" as early as $1631 .{ }^{39}$ According to the trial of the wife of the town councillor (senator) László Szücs in the same year: "her healing [method] was not legitimate". ${ }^{40}$ Mrs. Bálint Kis was accused in 1694 of "applying illicit means". ${ }^{41}$ Mrs. Mihály Kis performed healing "out of reckless ignorance, inside and outside the city, ignoring the power, as well as the origin and appropriate [healing] method for the illnesses", according to her 1715 trial. ${ }^{42}$ The text of her 1716 indictment states that Annók Fejér practiced an "unlearned profession". ${ }^{43}$ The judges in the 1720 trial of Mrs. István Csösz Varga accused her of "healing supra naturalem rationem". ${ }^{44}$ Mrs. András Bartha "fraudulently took 
the money, a couple of hundred Forints in total, of the poor patients; she would rightly deserve death," argued the prosecutor at her 1725 trial, who qualified her activities as "artificium probibitum". ${ }^{45}$ One of the charges against Mrs. Mihály Jóna in 1730 was that of "impostura in medicando" " ${ }^{46}$ Mrs. János Mózes also "healed by illicit means, ignorantly", according to her 1741 trial. ${ }^{47}$ In the same year Mrs. Mihály Szakolyi was accused of "being ignorant in the matter of medicine, yet she practiced healing; the man she treated got worse under her hands." ${ }^{48}$ In the indictment speech against János Kis in 1743, who had earlier been sued several times for his healing practices, it was said that "He practices medicine, while lacking the knowledge thereof, and he is more fit to do agricultural work." 49

The trials also reveal what the practice of an 'ignorant profession' consisted of, and what the condemned and illicit means were. In contemporary parlance, the 'healer women' and their male counterparts attempted to heal numerous exterior diseases (that is, with visible symptoms on the body surface) and interior ones, which, using the logic of witchcraft were qualified as bewitchments. Among the healers in Debrecen, for instance, Erzsébet Balázs (1693) tried to heal gastritis, delirium and fright; Mrs. Ignác Villás (1693) treated eye diseases, paralysis, maternity-related diseases, impotency, and fright; Mrs. János Nagy (1693) healed pimples, barrenness, insanity, indigestion (urinary problems). Mrs. György Kis (1702) treated epilepsy; Mrs. Mihály Szaniszlai (1711) tried to heal scall and abcesses. Mrs. András Bartha (1725) treated epilepsy, paralysis, heart-pain, colic, stomach and eye disorders, impotency and barrenness. Mrs. Mihály Jóna (1730) attempted to treat pustules, lesions, even syphilis (francú). Mrs. János Kis (1743) healed bone fracture, sore throat, asphyxia, insanity, lesions and even patients with the plague. ${ }^{50}$

The "healer women" and their associates usually used various medicinal herbs, preparing potions, baths, or fumigating the patient with them. In addition to using medicinal herbs, some trials mentioned other treatments, which also seem more or less rational. János Kis (1734) for instance used as "healing instrument none other than birch leaves, burnt alum, burdock and hops, of which he made a lye and washed the injured flesh with it, in order to protect it from rotting." The same healer bandaged the "head of a patient which had been injured and even split by a blow, with a little butter and onionskin." ${ }^{1}$ Mrs. Pál Marosi from Telegd (1766) treated pustules as follows: "I prepared medicine from mutton tallow, blue vitriol and a little rancid fat or grease." 52 Mrs. András 
Nagy from Debrecen (1730) simply smeared grease on the patients with "side and stomach hernias." ${ }^{53}$ Mrs. Mihály Jóna from Debrecen (1730) healed "all kinds of infirmities" with the following potion: "two types of incense, girispán, ${ }^{54}$ gunpowder, alum, blue vitriol and cherry tree resin cooked in wine vinegar covered with bread-crust". It was only Mrs. Jóna who we know also used some kind of "black substance" in her healing, a potion she bought in the pharmacy. ${ }^{55}$

These rational, and in many cases truly useful, remedies were coupled with certain elements which might be considered irrational from a contemporary point of view: in the popular medicine of the age, however, the two aspects were inseparably intertwined.

Mrs. Ignác Villás (1693), for instance, asked one of her patients for a bed-sheet, because, as she said, "they will extend it over a chain and they will cut the binding from this sheet". On another occasion, according to a patient, "she asked for a black chicken feather, then she took a handful of soil from under her feet, put it on my foot, and then took a silver needle and ploughed the earth with the needle and the feather while uttering incantations." 56 Mrs. János Nagy (1693) gave the following advice to a patient who had complained of her cow giving bloody milk: "Pour the milk over the wood-cutting stand and over the garbage, beat it hard, and the cow won't have problems anymore." Another patient was "fumigated and massaged with something like a candle wick." 57 Mrs. István Kis (1715), when she was healing a patient with little success, exclaimed: "if I could only catch a toad and bind 20 nails of the woman [who has bewitched the patient] to it, you would recover." 58 Mrs. Mihály Kis (1715) treated fright and palpitation with medicinal herbs and incantations: "when she boiled and prepared the bath, she took her bag of herbs and carried it to the stove and said the Lord's Prayer and the Nicene Creed over it. She then put the herbs in the bath and reiterated the prayers. After that the witness was seated in the bath, and, being thirsty, asked for something to drink, to which she replied, "May Christ give you his sacred soul to drink, and drink later". She had the witness seated nine times in the bath, naked. When the patient got out of the bath for the last time she gave her a broken human skull to drink from, and she poured cold water in it from a jug, putting some kind of herb in the vessel, upon which she uttered incantations." 59 Kata Szabó (1718) gave one of her patients "the heart of a turtle for heart palpitation." ${ }^{60}$ Mrs. Mihály Jóna (1730) gave as advice to a patient who believed that her daughter's illness was a result of evil eye that she should ask for three drops of blood 
"from the little finger" of the one who "saw her", and drip it into her daughter's eyes. ${ }^{61}$

As the trials occasionally reveal, some "healer women" from Debrecen had a fairly wide clientele, spreading beyond the city limits.

Despite the positive role these "healer women" played in their communities, in the period of our study they were already threatened from many sides by the danger of becoming identified as witches. The Calvinist Church unequivocally considered their activities as diabolic superstition, and, their judgment of popular beliefs in the period of the witch trials has also been seen as rather ambiguous, manifesting in some sort of awe, a sense of respect mixed with fear.

I cannot tell exactly when these individuals started to be seen as witches. It is nonetheless noteworthy that while from the mid-sixteenth century, that is from the period when Calvinism took root, we do encounter a few cases in Debrecen in which unsuccessful healers were brought to court, the accusation of witchcraft was not (yet?) pronounced. In March 1551, for instance, Antal Orvos (the surname means "physician") promised "according to agreement" to Lőrinc Nagy to "pay him one Forint for not having been able to heal his wife." 62 The servant János who was sued by his master, Márton Szép, in 1551 because his horse had been treated by János but had died, had to take an oath that the cause of the horse's death was not his medicine. The court ordered Márton Szép to estimate his damages and for János to reimburse him. ${ }^{63}$ Finally, in March 1557 a healer woman sued one of her patients for not paying her for her-presumably unsuccessful—'healing services' ${ }^{64}$ Apparently, these cases reflect a phase of the assumptions related to healers when "bad healing" did not mean more than being unsuccessful, and was not yet associated-either in the eye of the tribunal, or in that of the victims - with witchcraft. From the end of the sixteenth century, however, throughout the examined period-parallel to the establishment of Calvinism and of the Calvinist witch stereotype that claimed positive magic to be diabolical - the witch trials reflected an aura of suspicion surrounding healers from both sides. I have already presented the ecclesiastical side: let us take a look at the social side, that of the patients.

The trials reveal that there were various ways to begin one's career as a healer or a compassionate midwife and end up as a witch. Even though the process of 'turning' specialists of magic into witches had not concluded by the end of the examined period, it had manifested considerably. 
This idea is confirmed by the fact that one of the most frequent reasons for falling under suspicion was actually success in healing. When the midwife from Sámson, Mrs. János Fődi was called to heal somebody, she hesitated; for, according to her trial in 1746, "if I healed him, I would bring danger upon myself, I would incriminate myself." 65 The hesitation of Mrs. Födi, according to which healing, whether successful or not, could entail the suspicion of witchcraft, reflects a commonly accepted opinion in the age of witch-hunting: whoever could lift a spell was also capable of casting it. As one of the victims of Mrs. János Nagy (1693), a healer and midwife from Debrecen, claimed: "It is impossible for someone else to heal [a bewitchment], it can only be done by the person who caused it." 66 It is noteworthy that among the maleficium narratives related to the accused "healer women" and midwives, the incidents of successful healing were in fact in the majority. In Debrecen, the latter constituted two thirds of all cases (31.48\%, that is 41 failed healing cases).

Furthermore, many healing women and midwives resorted to various magical practices. Sometimes it was the unsuccessful application of these devices that placed them under suspicion. Mrs. Pál Sós from Debrecen (1693) "gave a caul to a hajdú (soldier) named Lukács SzentJóbi Török, so that bullets would not hit him." Despite this, the soldier was shot by the Turks at Várad. "And so the other soldiers caught her and took her to the ispán [head of the county court] saying that she was clearly a witch." $" 67$

Certain healers-in order to reinforce their prestige-used beliefs according to which people with extraordinary skills could hear and learn what others said about them, and were able to see things which happened out of their sight. Mrs. János Molnár (1693), for instance, "could tell right away whether my wife had or had not slept that night... she knew what she had dreamed better than if she had heard it... and she related everything that Mrs. János Szarka had dreamed." 68 Mrs. Mihály Jóna (1730), to the greatest surprise of her patients, reproached them for questioning her healing skills: "Mrs. Jóna told them right away, "Why don't you take [the patient] to someone who knows how to do it, since Mr. Komáromi has said that I don't know shit about it." Boasting about their special skills, however, proved to be a two-edged sword: instead of raising their prestige, it often served as foundation for their reputation as a witch.

It is also very interesting to encounter some maleficium narratives in which "healer women" and midwives are represented as the guardians of 
certain communal requirements, taboos and beliefs and it was precisely this fact which had led to the witchcraft accusations against them. Two "healer women" from Debrecen, Mrs. Pál Sós (1693) and Mrs. János Molnár (1693), had both warned their patients about the prohibitions on kneading and of nursing without a bonnet on Saint George's Day, something I mentioned earlier when discussing these dangerous times. These latter truly must have felt guilty for their offenses, because they all talked about how after the infringement they were "punished" (their children became ill). But, warding off the responsibility, eventually they interpreted their troubles as the bewitchment of the specialist of magic who had reprimanded them. ${ }^{69}$

Such and similar cases, primarily appearing in the urban environment of Debrecen in the late seventeenth and early eighteenth centuries, are probably referring to the early stages of a process-represented in the framework of maleficium narratives-during which certain requirements, forming part of the social norms, were slowly eliminated. The offenders were aware of their misbehavior according to the currently prevailing norms; but by accusing the "healer women" supposedly defending these very rules with witchcraft, they were practically denying them. And thus, indirectly, they also undermined the authority of the magical specialist.

I believe that the conflicts resulting from the denial of the privileges due to the "healer women", and about the violation of their differential treatment, appearing in the maleficium narratives are also "about" this process. From the early eighteenth century we often hear of the subsequent victim not paying the fees of healing, or finding the amount too much, or not paying the healer the due respect. ${ }^{70}$

The 1730 trial of Mrs. Mihály Jóna, a healer woman from Debrecen, for instance, included several maleficium narratives resulting from this type of conflict. One of her patients, as the healer woman claimed, was responsible for her own illness; it had happened through her own 'duplicity', because Mrs. Jóna "had not received a 25-inch ribbon from her at the marketplace." She warned another patient, saying: "Why hasn't your mother sent me chickens, she will have to send more." She asked in vain for the bonnet of a patient in which to travel to Nagysellye. The patient would not give it to her, and when she later became ill, she obviously attributed her condition to a bewitchment by Mrs. Jóna. She sent a message to a sick couple before visiting them to "prepare some food" because she was coming in the afternoon." She also reproached her former patient, Mrs. Kállai, for not paying for her healing services. As 
a witness explained: “Mrs. Sámuel Kállai came to the witness’s house and sat next to Mrs. Jóna in an armchair on the porch. Mrs. Jóna told Mrs. Kállai, "Listen, Mrs. Kállai, tomorrow you will have to send me some carp. She replied: Where should I get it? I can't buy any myself; I'll send you some other kind of fish. Mrs. Kállai then got up and left, and Mrs. Jóna shouted after her, "Do you hear me Mrs. Kállai! You better do what I told you, you bitch!"”1

Mrs. Mihály Jóna, when asking for the ribbon, the chicken, the bonnet and the fish, was protesting about failures to provide the customary privileges due to the "healer women". Her patients, however, when afflicted by an illness following their dispute with Mrs. Jóna, all considered it to be her bewitchment, and thus liberated themselves from the guilt felt from having violated a custom, and arguing against those expectations.

Another way for placing healers and midwives in a situation where they would gain a reputation for witchcraft, one which occurred in Debrecen quite frequently from the end of the seventeenth century, was apparently a result of rivalry among magical specialists. We can reasonably assume that within the wave of newcomers resettling in the city during and after the period of Ottoman rule, there were a fair number of popular healers and midwives, who had to earn their authority in rivalry with one another and with their counterparts already practicing in Debrecen. One way to achieve this, as is confirmed by the above-mentioned case of Mrs. György Kis who moved there from Böszörmény, was to boast about their knowledge wherever they could; they tried to outbid the skills of the rival healer and in order to earn and secure the trust of their patients they openly qualified their rivals as witches.

The traces of such a rivalry are to be found in the background of the trial of Mrs. András Bartha, a healer woman from Új Street, starting in 1725. Mrs. Bartha lived on the same street as the healer woman Mrs. Győző Marosi, with whom she had apparently entered conflict over healing the same patient. Mrs. Marosi told the story as follows: "About 2 years ago one of Mrs. Dóka's children was ill and was treated by Mrs. Bartha; Mrs. Dóka called the witness to take a look. The witness was not aware of Mrs. Bartha having already treated the child, so she went to take a look. On her way home she ran into Mrs. Bartha. She said, "Where are you going? you walk like a horseman, I am mad at you." The witness said, "Why are you angry with me? I have never done anything to hurt you." She replied, Yes you have, because you meddled with my 
work and went to see the child of Mrs. Dóka..." and she threatened the witness, saying, "Just you wait, you'll regret it!" She scolded her, "You are no better healer than I, because I can heal anyone I want to, no matter what the patient is suffering from." The following day, according to the testimony of Mrs. Marosi, the crows pecked her bread and cheese, and after she ate it, she became ill. She obviously attributed this to her conflict with Mrs. Bartha. ${ }^{72}$

One significant role in the rivalry and mutual accusation of healers was that the patients - as we have seen in the case of Mrs. Dóka-did not stay with one specialist, but went from one to the other, and they were easily persuaded to confirm suspicions of witchcraft concerning the less successful healer. The best example for this phenomenon is the case of the Újvárosi Szabó couple, residents of Péterfia Street who, between 1715 and 1725 , were accusers in no less than four witchcraft trials, against three healer women and the already mentioned Mrs. Márton Rácz. In 1715 Mrs. János Újvárosi Szabó made an accusation against Mrs. Mihály Kis, the healer from Varga Street; in 1718 she accused Kata Szabó, also a healer from Varga Street; in 1725 it was Mrs. András Bartha from Új Street whom she accused, partly for being able to heal neither herself, nor her husband, and this also developed into a witchcraft accusation. ${ }^{73}$

According to the 1725 trial records, Mrs. Bartha identified the "fairhaired fat red woman" living in the same district, Mrs. Márton Rácz the Újvárosi couple's neighbor in Péterfia Street, as the one who had bewitched them. She had uttered the following words when refusing to continue Mrs. Újvárosi's treatment: "Well, Mrs. János Szabó, last year I encouraged you that I was going to heal you, but I won't encourage you any longer, because a blond fat red woman came here in green coat, green bonnet and blue skirt, she moved in across your house in the same row as the smith, and she would not let me heal you... But beware of her, because on the third day, if she can take something from your house or from your merchandise, she will take it, but don't give anything to her, because if she is able to take something no one will ever be able to heal you."

Mrs. Újvárosi related to the court in the most vivid terms her encounter with Mrs. Rácz: how the suspicion Mrs. Bartha had planted in her grew to fill her soul: "The witness was sat next to her few goods for sale in the market when Mrs. Márton Rácz and Mrs. Harsányi came straight up to her and stopped in front of her stand. One of them, she did not remember which, picked up a piece of linen, and Mrs. Rácz said, "My 
dear neighbor, give me linen enough for a shirt." The witness was horrified, she remembered Mrs. Bartha's words, and suddenly replied, "I have no linen for you, you don't need it anyway..." Mrs. Rácz stood there for a while with the merchandise, then left all of a sudden without saying a word to anyone. Mrs. Újvárosi thus saw her suspicions confirmed, and in the witch trial she claimed to be the victim of Mrs. Márton Rácz.

Nonetheless, she also testified against Mrs. Bartha, who was unable to heal her, and who was offended because, while she was still her patient, she went to see the barber in Zilah (Zalău). Accusations were also laid at Mrs. Bartha by Mrs. Újvárosi's husband, who claimed that Mrs. Bartha had become angry with him, as well, for taking his wife to Zilah. One night Újvárosi "felt an agonizing pain: around midnight he was struggling with a woman [who] twisted his male member really badly."74 Naturally, he believed that he recognized Mrs. Bartha in the woman.

The Péterfia Street censuses between 1728 and 1730 reveal much about the real problems of the often sickly Újvárosi Szabó family, who frequently resorted to witchcraft accusations. Újvárosi was registered in the 1728 census as a small trader, with only one bowshot of land and a vineyard of the same size. Even though he lived in a house qualified as "mediocre", every sign suggests that he was gradually going broke. In 1730 , for instance, the census takers no longer mention his trading activities, merely writing that he "lived off his four horses", and that he had one cow less than before. It seemed as if his personal life had also been full of tragedies. While in 1728 he still lived with his son, according to the census in 1730 "all his household had left him", and they also noted that "his wife was mentally disturbed", which could be an explanation for their frequent witchcraft accusations. ${ }^{75}$

Rivalry between neighboring "healer women", patients seeking treatment from several healers, personal tragedies of the victims, neighborly animosities and breaking the norm of the "God-fearing honest woman" all appeared in the trial conducted by the magistrate in 1730 against five accused inhabitants of Upper Debrecen. The indictment documents of the trials of the "healer women" Mrs. Mihály Jóna from Mester Street and Mrs. András Nagy from Hatvan Street, and of three other persons from Mester Street (Mrs. András Vezendi, Mrs. Péter Kovács and Mrs. János Szentesi) interpreted the events as follows: the accused "started to trade with God-fearing Christian people as part of her pact with the Devil, with the help of similar evil companions. After she bewitched somebody, she had her companion tell them to go and 
see this or that healer who would be able to solve their problems, and in exchange for payment that person healed people who were bewitched by her companions. They were able to heal with the permission of the other companions."76

The truth behind the conflicts which reached their conclusion in the 1730 trial was actually completely different from what the indictment document reveals, and could be traced back along multiple strands to a much earlier period.

The lodger of Mrs. János Nagy in Péterfia Street, the widow of András Vezendi, had been sued by her neighbor, Mrs. Péter Kovács back in 1719, because Mrs. Vezendi had falsely accused her of witchcraft. ${ }^{77}$ Mrs. Vezendi was then looking for a cause behind her child's and her own illness, and, as it later turned out, "Péter Tátos" from Hajdúnánás and the healer woman from Gelse, Mrs. Majláth, both diverted the suspicion to Mrs. Péter Kovács: "the one who lives three houses from her place, she is the one who ate her child."78 Mrs. Kovács probably won the trial and Mrs. Vezendi was probably sentenced to pay a fine for slander. I do not know if there was anything more to the conflict between the two women; Mrs. Vezendi, nonetheless, was still accusing Mrs. Kovács in 1730, who was sued by the court.

Mrs. András Nagy lived in Hatvan Street and had a reputation as a healer. She proudly bragged that she had learned her skill from her mother. Her past, however, had been blemished several times, which might have been a factor in her reputation as a witch. Her father had been punished earlier for unknown reasons. The daughter tried in vain to prevent his conviction by magical means: "she took sand and herbs from the bellies of nine dead people and scattered them on the thresholds of the town hall." In 1726 she was also punished for having committed adultery with a widowed man called István Mellyes. Her husband, who was not leading an exemplary life either, took her back, but the memory of this incident apparently dogged her for a long time. In the 1730 trial several of their neighbors testified to their frequent quarrels, mutually accusing each other of leading an immoral life: "Mrs. András Nagy said to her husband: you are a rogue. He replied: you are a whore. To this she said: that other time you drowned that woman with her child [i.e. András Nagy's mistress]. The husband replied: and your daughter, it was not me who made her, I saw when you made her with someone else."79 During these fights András Nagy often reproached his wife, saying that the their daughter was not his but that of her former lover, Mellyes; he 
also accused his wife of having bewitched him in the course of her trial as a witch: he was "suffering, has no virility and desire, and could never inseminate a woman."

Mrs. András Nagy treated patients both in the street where she lived and in Mester Street. Her damaged reputation might have favored the other healer woman who had recently moved to Mester Street, Mrs. Mihály Jóna, who thus hoped to acquire Mrs. Nagy's patients and so that she could build her own extended clientele. At least in the beginning; as we will see, she later had her own reputation problems, among other troubles.

In the spring of 1727 the Jóna butcher family was still living in Csapó Street, where on 27 March their slaughterhouse was set on fire. ${ }^{80}$ I was not able to discover the background to the affair; according to documents the fire devoured the greater part of the town. Jóna's house was probably also burnt to the ground, because in the winter of the same year they were already residents of Mester Street.

There they bought the house of the debt-ridden Gergely Dömsödi, a failed tailor. In 1746, at the request of his sons, his debts were assessed, and witnesses stated that most of his wealth had been estimated on the basis of claims by the trimmers of Kassa (Košice). Besides the people from Kassa, Dömsödi was indebted to many others. According to neighbors' testimonies "his house... and many parts of his land, his horses, his carriage and other cattle and even his wooden shaft were due to be assessed by his creditors. Gergely Dömsödi was probably left with nothing outside his debt, he could not leave anything to his offspring... he did not have enough to pay for a proper burial for his stepmother, she was buried in her under-garment." The poor tailor "ended up in such poverty that he could barely provide bread for himself." 81

It never transpired whether the Jóna family had paid his debts in Kassa and to the other creditors in order to buy his house, or if they took on his debt with the house. It is certain, however, that they turned the Dömsödi family into their own debtors and they threw them out of the house. The bankrupted couple was probably taken in by one of their neighbors in the street. The desperate Dömsödi couple, however, did not give up their home easily to the Jóna family; or if it had to be given to them, they wanted to cause some trouble as the Jónas set up residence. In 1727 Mihály Jóna wrote a letter to the tribunal because "Mrs. Dömsödi had the hedge destroyed in front of their eyes, she cut down the plants in front of the house... she said unseemly things so that the 
whole street could hear... she cursed heavily, saying, 'You will see, you will never have God's blessing on this estate, and He shall never give it!' She also told the house servant, "[Jóna] shall never live in peace in this house... I would rather see the house burn, than to see him stay here.'” Mrs. Dömsödi considered the fire in the spring also to be among Jóna's sins: "No wonder that God had this town burn twice, I'm afraid we will [burn] for a third time as well." 82 By this she probably meant, as I have mentioned earlier, that the fire was God's punishment for the Jóna family's sins.

After the Jóna family settled in Gergely, Dömsödi tried to provide for his wife and daughter and to pay his debts—among others to Jóna—as a "meadow inspector", that is, a keeper. In the witch trial, his wife stated that they had also given axes in pawn to the Jóna family. One time, when Mrs. Jóna came to pick up the axes, the desperate Dömsödi wanted to beat her- "to axe her", as the woman phrased it in front of the courtbut the axes, for an inexplicable supernatural reason, were nowhere to be found, and only appeared after Mrs. Jóna was gone. Mrs. Jóna's interpretation of the incident was that the reason Dömsödi could not find the axes was not her witchcraft, but his own drunkenness.

By the time of the witch trial in 1730, Gergely Dömsödi was no longer alive. He must have died at a young age, because his wife at this time was also only 30 years old. He might have ended his own miserable life: Mrs. Dömsödi, nevertheless, attributed all their troubles and the death of her husband to Mrs. Jóna; she also believed that it was Mrs. Jóna's bewitchment that was responsible for her daughter's having "no luck", and being unable to find herself a husband. She complained in front of the court that "neither her, nor her daughter had peace of mind during the night" because of Mrs. Jóna, and that "she had found some things that were put inside her own pillow."

In December 1727, another note was sent to the tribunal from Mester street. It was written by the farmer József Kálmánczy, who had become the Jóna family's immediate neighbor when they moved in. Kálmánczy gathered the testimonies of four other neighbors to list his problems with the Jóna family. The conflict stemmed apparently from the disagreement on where to set the fence between their properties. It is possible that Kálmánczy had tried to ensure a bigger piece of land for himself, assuming that the new neighbors would not know the exact size of the property they had just bought. According to the document Jóna and his wife "declared themselves judges of the matter and obstructed 
[Kálmánczy] from weaving the fence"; moreover, they destroyed what he had already woven and stole his sticks. This, obviously, led to fierce quarrels between the two parties.

Kálmánczy informed the court about Jóna and his wife not going to church, and that they lived a scandalous life, quarrelling frequently: "Mihály Jóna claimed that his wife was an arsonist witch whore, and told her that he would have her burnt the next day." Kálmánczy also informed the magistrate: "Since [Jóna and his wife] have threatened me, I protest that, should any damage happen to my house, myself, my servants, my wife or my cattle, I will hold them responsible, since they were the ones who threatened me." 83

The neighbors, including Kálmánczy, were annoyed by the fact that when the Jóna family bought the house of Dömsödi, they had violated the legal custom prevailing at the time in Debrecen, namely that anyone intending to sell a house should give the neighbors first refusal. Quite the opposite: the Jóna family who, moreover, were considered strangers in the street, had moved in right away. Three years later, Kálmánczy accused Mrs. Jóna in her witch trial of her wanting to poison him and his family; he had found "poison" in one of his pots. The second wife of Kálmánczy had died before the witch trial. When they put her in the grave next to his first wife, they allegedly found a "new pierced pot with its lid" by the head of the deceased, which they interpreted as further proof of Mrs. Jóna's witchcraft. In her witch trial, Kálmánczy held his neighbor responsible for the death of both of his wives. Another neighbor testifying in the 1727 interrogatory, the wife of Mátyás Csermák, also testified against Mrs. Jóna 3 years later in front of the court. She said that "someone bit my neck during the night in my sleep", and she believed she recognized Mrs. Jóna in the perpetrator, who "had a dog catch all the hens in the neighborhood, and when she was reproached for it, she became angry and cursed." The dog was eventually shot by Kálmánczy himself.

Thus, the suspicions against the Jóna family were aroused from the moment of their tempestuous arrival in the neighborhood; their neighbors were very likely to attribute their misfortunes and troubles to the Jóna couple. Mihály Jóna had "only" violated custom when he bought the house in Mester Street before the neighbors had been consulted; his wife, on the other hand, who also pursued activities as a healer woman, was known to be a norm-breaker and a person "of ill repute". Besides her avoiding church, several witnesses testified to her frequent 
drunkenness, adultery, profanity, some even accusing her of irreligiousness. One of them "heard that Jóna disparaged her wife, saying she was a witch whore, he also said that he was going to have her banished from Debrecen, because she had called her husband a son of a bitch. When the husband of the witness heard all this cursing, he told her that the Lord Almighty would punish her. [Mrs. Jóna] replied greatly annoyed: where is God? She blasphemed terribly and she has nothing godly in her; sometimes when her husband admonished her she had slapped him or tried to strangle him: it was the witness's husband who had rescued him."

Eventually it was not the angry and suspicious neighbors who sued Mrs. Jóna, but a patient from Hatvan street, János Jenei. Jenei and his wife first sought healing from Mrs. András Nagy, but then they changed to Mrs. Jóna. Mrs. Jóna naturally accused the former healer, Mrs. András Nagy, of having bewitched the Jenei couple. Mrs. Nagy, when she heard that their new healer was Mrs. Jóna, said: "If only you [Jenei] hadn't called that horrible woman, I would have finished it."

The third accused in the trial, Mrs. Vezendi, an old widowed lodger, appeared often at the side of Mrs. Jóna, trying to reinforce her reputation as a healer. This was visibly with the sole goal of taking a share of the privileges due to "healer women": wine, brandy, and food. When, however, Jenei-whose illness did not get any better-started to suspect Mrs. Jóna, interestingly Mrs. Vezendi also turned away from her, and started to contribute to the suspicions laid by Jenei. She said, for instance, in their presence: "I would put my hand on her head and even swear in front of the council that she is a true witch; she is also teaching the profession to her son." For the complete picture we should add that Mrs. Jóna had a handicapped son: he was very short and had a very big head. Allegedly his head had once split open when a neighbor's dog had jumped on him, and Mrs. Jóna had boasted to others, saying that she had "put him back together".

János Jenei, when he finally became completely confused about the three mutually accusing women, had hidden three of his neighbors in the house and invited Mrs. Jóna and Mrs. Vezendi to come over. He diverted the conversation to Mrs. András Nagy, and reproached Mrs. Jóna: "you poisoned me together, now heal me together." Mrs. Jóna, perhaps out of anger, confirmed this by saying: "We poisoned you together and we'll heal you together, just pay us." Then the hidden neighbors came out and grabbed Mrs. Jóna to take her to the judges. 
The woman had sighed: “Oh, oh, I wish your good wine was lost, you have invited me to a bad dinner." 84

Eventually Mrs. Mihály Jóna was sentenced by the tribunal to be banished from town, as was Mrs. András Vezendi. The verdict on Mrs. András Nagy and the other two accused is unknown.

Similar to the 1725 trial of Mrs. András Bartha, it was once again the rivalry of the "healer women" living close to one another and trying to acquire each others patients, and the resultant loss of confidence on the part of their patients that all played a significant role in escalation of events into a witchcraft trial. In the case of Mrs. Vezendi, Mrs. Nagy and especially Mrs. Jóna, the witnesses' testimonies revealed situations of conflict exacerbated by multiple tensions such as we have observed in the case of the above-discussed group of accused witches "of ill repute". Apparently, the dangerous relations generating suspicion of witchcraft also frequently occurred cumulatively in the case of women healers, even though the maleficium narratives told during the witch trials either keep silent about these relations, or only represent the existence of one or two such connections.

Beyond the incidents I have described-at least in the case of Debrecen-there was another conflict latently influencing the adjudication of the specialists of magic and stemming from contemporary local cultural and social history, which was also rarely mentioned explicitly in the maleficium narratives: the issue of 'legitimate' and 'illegitimate' healing and midwifery.

Behind the issue, phrased by a Debrecen magistrate in 1730 , lies the accusation, among others, according to which the accused 'healer women', by 'trading' the illnesses of their patients among one another, were not only exploiting the gullibility of their patients but also violating the sphere of interest of the representatives of 'legitimate healing'. This occurred, on the one hand, through their intention to meddle with the function of divine providence, and thus desecrating the mostly prioritized spiritual sphere of the legitimate healing methods of the time. On the other hand, they were (literally) intruding into the physical and material sphere of legal practitioners of these healing methods: the barbers, who were considered to be the official healers of 'external' illnesses, and the physicians, who had the privilege of treating 'internal' maladies.

It is noteworthy that the gradual institutionalization of healthcare took place in the course of centuries when witch-hunting was in its prime. The example from Debrecen suggests that the two phenomena 
were not independent from one another, and that the gradual and increasingly articulate distinction between the 'legitimate' activities and those qualified as 'illegitimate', explicitly or not, became manifested in the witch trials.

In Hungary, until the establishment of the Faculty of Medicine of the University of Nagyszombat (Trnava) in 1769-1772, there was no university-level medical, surgical or midwifery training. ${ }^{85}$ These professions gradually created their organized structures over the course of the sixteenth to the eighteenth centuries, the institutionalization of the different fields occurring with varying intensity-usually primarily in urban environments.

In the market town of Debrecen the concentration into guilds of the surgical profession took place quite early — fourth after Tokaj, Nagybánya (Baia Mare) and Sárospatak. The first guild regulation was published in 1583. During the seventeenth and eighteenth centuries, however, only nine masters, and approximately 30 people in all including apprentices, servants and the widows of masters, were allowed to practice the profession in a town of more than ten thousand inhabitants. The profession of barbers, according to guild regulations, specialized in the healing of injuries from being hit, cut, shot, etc., or some other "external" impact, and of furunculous, pustular diseases visible on the surface of the body. The new guild regulation from the beginning of the eighteenth century only reinforced the traditions: again, they maximized the number of barbers at only nine. ${ }^{86}$

Debrecen had no official physician until the beginning of the eighteenth century. In the seventeenth century, medicine was only practiced by some preachers who had acquired a diploma from foreign universities and by some college teachers. ${ }^{87}$ The first medical office was established only after Debrecen acquired the title of free royal city in 1700 . The office was first occupied by István Huszti Szabó, the court physician of Prince Mihály Apafi, who had studied his profession in Germany and the Netherlands; although he only stayed in office for 4 years.

Apparently the office was occupied on a regular basis only from the 1730s. From this period onward, on the other hand, there were prestigious figures practicing in the city, such as János András Segner (in 1730), who later became a professor at the University of Jena; György Buzinkai (from 1737) who graduated in Franeker and wrote an up-to-date dissertation on the prevention and the treatment of the plague; István Hatvani, who had by then acquired a many-sided scientific education 
(from the end of the 1740s); István Weszprémi (from the 1760s) who graduated in Utrecht, and had correspondence with van Swieten, court physician of Maria Theresa and one of the great opponents of witchhunting; finally, the stepson of the latter, József Csapó, who published a book on medicinal herbs and a dissertation on pediatrics. ${ }^{88}$

The first pharmacy was established around 1670 and financed by the city; then, in 1714 it was placed under the supervision of the medical officer. Until the 1770s, one single pharmacy was supposed to supply several thousands of inhabitants of Debrecen with medications. This, however, as the shortage of medication during the 1739-1741 plague epidemic shows, was insufficient. The second pharmacy was established only in $1772 .{ }^{89}$

A hospice for the poor operated from the beginning of the sixteenth century in Debrecen; a newer establishment was founded in the seventeenth century, and during the 1739-1741 plague epidemic the city doctors established a temporary health centre. A permanent hospital, however, was only established in the first half of the nineteenth century. ${ }^{90}$

Considering the rather low early modern standards of institutionalized, official healthcare, popular medicine must have satisfied a wide range of social demands. These alternative healing methods were still flourishing in the eighteenth century, as the one single health officer and the nine barbers were hardly able to treat every patient in a city inhabited by thousands. The process of increasing institutionalization and of improvement, however, also had an impact on the adjudication of the activities of popular healers: the barbers, and then particularly the eighteenth century physicians declared their healing methods to be 'illegitimate', as were their interpretations of illnesses in the context of witchcraft. In the case of Debrecen, one can clearly recognize the process in which, during the eighteenth century, the official physicians required more and more barbers and midwives to distinguish their activities from those of the 'illegitimate' equivalents, whose pursuits they considered useless (being based on superstitious instruments and concepts).

The city physicians in the eighteenth century not only obtained supervision of pharmacies, but abiding by certain central regulations, they tried to control the activities of barbers and midwives, and sought to improve their level of training. While, in case of a serious injury, the sixteenth and seventeenth century barbers' guild regulations only prescribed that the barber treating a patient should inform the guild master who had to have a consultation about the patient ("call the guild on 
him"), the 1736 guild regulations approved by Charles III state that "the presence of a Doctor is required" in such cases. The new regulation also stipulated that "if patients with external wounds and injuries require internal medicine, the barbers are not allowed to prescribe any medication without the advice of a doctor, other than decoctum, purgation or sudatory", and it strictly ordained that "without a word from the Doctor, one cannot even perform a venesection on difficult patients". ${ }^{91}$

In the $1750 \mathrm{~s}$ and $1760 \mathrm{~s}$ the decrees of the Royal Council of Governors ordered that those who wished to join the barbers' guild would have to pass a higher level exam than before (knowing how to prepare six ointments), and they have to do that in front of official physicians. Moreover, the 1761 regulation made it compulsory for barbers to pass a theoretical exam on the anatomy of the human body and on illnesses. ${ }^{92}$

We have to note the 1761 regulation issued by the city of Debrecen in which they modified the subject of examination of barbers according to the requirements of the Royal Council of Governors. The Chirurgorum Examen was compiled by the physician István Weszprémi in a 'question and answer' format, from which we learn that the profession of barbers was associated with the healing of "infirmities, lesions, fractures, sprains, lumps, furuncles or ulcers treatable by hand, external instruments and external medication". Weszprémi's exam questions were especially directed at the last of these. He demanded that barbers think rationally when treating pimples and pustules, as if he was instructing them to reject the standpoint of "healer women", who qualified these infirmities as maleficium. For example: "Question 87. What do you think of people with wounded legs who claim that they have stepped into a 'pouring' (öntés $=$ a kind of 'liquid' magical harm that causes illness) or that they have been bewitched? Answer: These lesions are called Ulcera Magica or fascinatio inducta, they are inventions of superstitious minds, because all these lesions have natural causes. One cannot attribute them to the Devil or to witches because God has not given them such powers." 93

The profession of midwifery was only institutionalized in Debrecen from the beginning of the eighteenth century, although we know of a council regulation from 1696 which obliged them to take an oath: "Midwives, who thus far have practiced their profession without faith and without order, should now be bound to their service by faith, for being more righteous, pure and honest in their office."94 The guildlike institution itself, the 'Association of Old Women of Debrecen', 
was founded only in 1738. It was directed by two 'master women' and supervised by the city physician.

The endeavour to consciously distinguish 'legitimate' from 'illegitimate' activity also occurred in the case of midwives, on the one hand, in the establishment of the midwife guild itself and also in the fact that the 'old women' were required to take an exam in front of a physician before entering the guild. On the other hand, and almost significantly, it became a requirement for practicing the profession that the midwives "abstain from any superstitious act and whispering around childbirth, because if someone is caught doing so she will be punished and disbarred from the profession." 95

The institutionalization of public healthcare and the improvement of its standards in Debrecen however did not directly correlate with the dismissal of witchcraft beliefs and the end of witch trials-as Ágnes R. Várkonyi has proposed to be the case on a national scale. While in the eighteenth century, the city physicians' fight against 'illegitimate' healing and midwifery by denouncing magical tools and concepts was indeed associated with an enlightening activity in the name of rationality, the barber's guild and the midwife's guild apparently often looked upon the struggle against 'illegal' healers and midwifes as mere rivalry-maybe on the basis of the traditional pattern of the competition among the specialists of magic. A most efficient instrument in this fight turned out, again, to be accusations of witchcraft.

In the case of the midwives' guild, considering that its existence as an organized structure came about rather late, it is understandable that such accusations only came at this point; by contrast, in the case of the barbers' guild, which had existed since the sixteenth century, some explanation is required as to why the guild members only started to appear as accusers in the eighteenth century. Naturally one cannot exclude the possibility that the rivalry between guild healers and popular healers had been present in the form of witchcraft accusation in earlier periods as well; the difference being that trial documents did not record the occupation of the accusers. There is, however, another explanation, which, in my opinion, is just as plausible. After the end of Ottoman rule, however, when the town earned the rights of a free royal city and had to integrate into the new centralized state order, the barbers, similar to many other guilds, had to reinforce their guild regulations in order to maintain their privileges. This happened in 1736 with the aforementioned modification that the new guild regulation allowed a greater involvement of physicians 
in the activities of barbers. Over the course of the eighteenth century the guild was gradually placed under the supervision of the city physician practicing in the spirit of centralized health regulation. The pressure thus weighing down on them, the mistrust of the medical officer towards their professional skills could explain why, at this point, the barbers turned against popular healers with greater energy than before, and why they tried to keep their patients by every means-even if this meant resorting to witchcraft accusations.

It seems, thus, that witch-hunting in Debrecen was "enriched" with a new aspect in the first half of the eighteenth century. The 'legitimate' representatives of healthcare contributed to the intensification of this persecution after Ottoman rule. Between 1735 and 175953 witchcraft accusations were made in Debrecen: in 18 cases the accusation was against popular healers and in seven cases against midwives. Thus, almost half of the witchcraft accusations targeted the representatives of 'illegitimate' healing and midwifery. Let us look at some examples.

Mrs. János Csutó was accused of sorcery in 1745. The woman was reported by the barbers' guild itself: "In the name of the honest Guild of Barbers the guild master proposes to punish Mrs. Csutó, who undertook the healing of a little girl who had broken her hand when she fell on the ice. She has been treating her for 16 weeks, and this has worsened her injury even more." 96 János Kis, a "shepherd doctor" from Berekböszörmény who moved to Debrecen without the knowledge of the council, was sued five times between 1743 and 1748. His first suit in 1743 stated that "He practices medicine, while he lacks the knowledge to do so and he is more fit to do agricultural work; he acts against the privileges of the honest barbers' guild in other ways as well, and perhaps he performs his healing with charms." Several of his patients mentioned that they had turned to him after the barbers had failed to heal them. For instance, one of them said that "The chin of a poor woman dropped, we took her to Mr. Kémeri, who wanted to call the guild, [but] János Kis put it back." Another patient "had his arm dislocated after falling off a horse. Mr. Veszprémi and Mr. Kopácsi treated him for 3 weeks with no result; this poor man healed him in 3 days."

Such cases obviously strongly undermined the professional authority of barbers; moreover, according to the witnesses some people were even afraid to seek their help in the first place. The third patient of János Kis, for instance, said: "The bones in my hand were broken, because I fell off a tree; Mr. Veszprémi and Mr. Borbély wanted to call the guild, 
but I did not dare to let them treat me, because they only healed with vinegar. It was this poor man who healed me." In 1743, however, the barbers could not get János Kis convicted for sorcery. ${ }^{97}$ In May of the same year they also accused him of drunkenness and blasphemy, and of "cheating and seducing everything in the name of healing". They were only able to rid Debrecen of him by December, when the court banished him from the city. ${ }^{98}$ That notwithstanding, in November 1746 a new trial was conducted against him. The tribunal asked the barbers to report on him if he had "healed someone despite the ban". ${ }^{99}$ In vain was he banished from the city once again: 1 year later he was standing in front of the council once more. This time his wife, whom he had left in Berekböszörmény, came to get him. He was proscribed again. ${ }^{100}$ Two years later he returned to the city. This time he was accused of causing the death of one of his patients; according to the indictment "he gave such a strong beverage [to the patient] that he vomited a deal of congealed blood." The beverage was examined by the city physician, György Buzinkay himself, according to whom "it was terrifying to look at it, let alone to taste it." According to the testimony of János Kis it was a concoction against a cold, and it must have been effective, since "it was made of ginger, cloves and honey." The 'shepherd doctor' was probably banished from the city once again; and since these are the last data on his activities in Debrecen, it seems as if the barbers' guild had finally succeeded in getting rid of their competitor. ${ }^{101}$

The widow of Sámuel Szathmári, who practiced 'illegitimate' midwifery, was reported to the tribunal by the 'Association of Old Women of Debrecen' in 1744. She was accused of "healing with charms and magic, and having called sworn midwives, namely Mrs. Aranyi and Mrs. Garai, to be witches", and of "telling misleading nonsense and lies...about a huge toad, which lay on her chest during the night, and who was no other than Mrs. Aranyi." Mrs. Sámuel Szathmári moved to Debrecen, illegally, as a newcomer. She was born in Nagyenyed (Aiud), and married in Kolozsvár (Cluj-Napoca), but her husband became a major in the Pálfi regiment and left her. After that she lived in Nagybánya (Baia Mare) and Diószeg (Tuta), and earned her living from midwifery and healing. She wished to continue practicing her profession at her arrival to Debrecen, and as we have seen in the case of many other 'healer women', she boasted about her skills, and called her rivals witches. However, she forgot one thing: that at this point, behind the midwives Mrs. Aranyi, Mrs. Garai and Mrs. János Oláh, whom she had denounced as witches, stood 
the 'legitimate' institution of the midwives' guild protecting them. It was especially unfortunate that she had been bragging about her magical skills in the presence of one of the matrons of the Association, Mrs. István Zsíros, and her daughter: "What kind of an old woman are you, Mrs. Zsíros, that you cannot do it; if you wanted you could arrange that the parents had their next child 2, 3, 4 or 6 years later." Because according to Mrs. Szathmári the number of knots one tied in the umbilical cord was equivalent to the number of years before the mother would have another child. At her trial one of the witnesses against Mrs. Szathmári was none other than the inspector of the midwives' guild, and swornin midwives also interrogated her on her professional knowledge (for instance, on what she knew about blood flow). Since her knowledge did not meet the then required standards of 'legitimate' midwifery, and she was also convicted of some kind of magical act, the magistrate sentenced her to be flogged with 24 lashes and banished from Debrecen. ${ }^{102}$

As well as the case of Mrs. Szathmári there are other trials that also confirm the protection the midwives' guild provided to its members against witchcraft accusations. Mrs. György Aranyi, the wife of a bootmaker and a sworn midwife, who had come out unharmed from the previous trial as well, was sued several times between 1740 and 1746. In 1740 she was accused of "having charmed and bewitched a child because the parents did not call her to the childbirth, as they had done before; she tied him with nine knots... the tiny infant miraculously jumped off her mother's lap." Mrs. Aranyi denied the 'superstition', and claimed that the child "had fallen off her mother's lap because the mother was drunk." She most probably won the trial, and was not relieved of her office, because in 1741 and 1742 she appeared again as a sworn midwife in the new proceedings against her. ${ }^{103}$ In 1742 she initiated a slander suit against the bootmaker's wife, Mrs. Ferenc Fónyi, for calling her a witch. Despite eventually losing the trial, because her accusers proved that "she wanted to heal [Mrs. Fónyi's child] by binding nine knots and she had performed several magical acts as well", once again she could stay in office, only receiving a caution. ${ }^{104}$ In 1746 she was eventually suspended from exercising the profession of midwifery because, as the trial documents put it, she rarely went to see the women after childbirth, and she exhausted them. Witchcraft was not even discussed. ${ }^{105}$

Mrs. János Oláh, a sworn midwife, launched a slander suit in 1749 against János Pesti and his kinsman, Mihály Csóka. Mrs. Oláh had assisted the wife of János Pesti after childbirth. When the newborn baby 
became ill, the Pesti couple took the infant to the 'shepherd doctor' from Hadház, who identified the midwife as the bewitcher of the baby. After this Pesti and Csóka called Mrs. Oláh over and Mihály Csóka called her a "diabolical witch". The trial was once again won by the sworn midwife, who enjoyed the protection of the guild, and the defendants were punished. Csóka was sentenced to eighteen strokes of the birch for having called her "diabolical". In addition, a new investigation was started against János Pesti and Panda Sós, who suggested turning to the 'shepherd doctor', and for "acting against their Christian duty and seeking the help of a charming sorcerer."106

No similar witch trials suggesting the conflicts between 'legitimate' and 'illegitimate' healing or midwifery were found in other places in Bihar County. This is presumably because neither of the two professions had reached a level of institutionalization similar to that of Debrecen, not even in the market towns. According to the research of Gyula Varga, in the market town of Kismarja there was only one barber active in the eighteenth century, and only two or three women performed the function of sworn midwives. ${ }^{107}$ In Berettyóújfalu we know of only one midwife from 1721 and one 'physician man'. ${ }^{108}$ In Konyár in the eighteenth century there were only a few 'bonesmiths' (bonesetters) exercising healing." 109 There were no guilds for barbers or midwives in operation in the smaller settlements of the county, or if there were, they were not really institutionalized.

The healer-midwife-patient relationship, and the circumstances of their interaction in early modern Debrecen implied some kind of uncertainty. The trials that we have examined reveal quickly dissolving and quickly reestablished relationships, as is perhaps best illustrated by the case of Mrs. János Szabó from Újváros. Going from one healer to another often resulted in the former healer being accused of witchcraft. The witchcraft accusation in this case reassured the patients and their relatives that it was not the illness that was incurable, but the specialist who had been inadequate. The competing healers, as we have seen, only confirmed these opinions when they tried to build or defend their prestige by identifying other specialists as witches.

In the long run, however, this type of rivalry might in fact have entailed the decline of their prestige. We have seen that several witch trials started with the confused patient not being able to make head or tail of the mutually accusing healers, reporting both of them to the court under suspicion of witchcraft (as for example András Szabó in 1694 or János Jenei in 1730). 
Existing or future patients may have heard of the reputation as witch of many of the healers in their surroundings, as they might also have heard condemning opinions emanating from representatives of institutionalized, 'legitimate' healing, supported 'from the top' by the magistrate and the tribunal. Over the course of the eighteenth century these representatives tried to convince them with increasing vigour of the fact that traditional healers and midwives were-in the better cases'superstitious' people, or worse, as we have seen in the case of the barbers' or midwives' guild, that they were witches. Under such circumstances, I believe that the chances were pretty high that the trust of the people of Debrecen in the traditional specialists of positive magic would have wavered. The aforementioned conflicts could be related to this change in perception, which was partly due to the victims violating social norms apparently supervised by healers and midwives, and partly due to the traditional privileges and traditional requirements expected by these healers failing to be provided. The fact that the victims attributed any problems occurring after such conflicts entirely to specialists in positive magic indicates that to a certain extent the population had turned its back upon these specialists and rejected the norms relating to them.

The witchcraft accusations appear as if they represented a change in the mentality of Debrecen: instead of the traditional expectations, they point towards a new kind of norm. We can say the same thing about the cases in which the 'legitimate' healer barbers and midwives used witchcraft accusations to get rid of their 'illegitimate' rivals. The accusation-paradoxically - once again favored the new, the establishment and reinforcement of the official and institutionalized framework of urban healthcare. At least this is what is revealed by the maleficium narratives, which in this perspective were created in a well-discernible sociocultural environment.

\section{Problems of Neighborhood, Cohabitation and Poverty}

Mátyás Nógrádi describes 'humble status' as being one of the features of the popular witch stereotype. Poverty, as the preacher claimed, predisposes people to resort to magic. Imre Haász, an early researcher of the Debrecen witch trials, was of a similar opinion concerning the accused in the city: "the unfortunate victims of witchcraft beliefs usually came from the lower social strata."110 
Neither in Debrecen, nor in other parts of the county were the witch trials well documented enough for me to assess the role of poverty in the emergence of witchcraft accusations. I found it opportune to treat the scattered relevant data in terms of the category of cohabitation and neighborhood, since the majority of poor witches were lodgers. The relationship between the victim and the witch in the known cases, as we have seen, was mostly defined by cohabitation or neighborhood. The former occurred in $38.57 \%$ of the spatial relations in Debrecen and $37.03 \%$ in the county, while the latter can be found in $63.26 \%$ of the Debrecen cases and $33.33 \%$ in the county.

The conflicts between people living in the vicinity of each otherneighbor and neighbor, lodger and landlord-and the accusations of witchcraft accusations originating from them have already been illustrated through several examples from the trials we have examined. Furthermore, a specific type of accusation, from 'above', where the landlord accused his lodgers of witchcraft, seems to have been somewhat common, especially in Debrecen.

Being a lodger truly did entail a 'humble status', both in the city and in the other market towns and villages of the county. Lodgers did not own a house and, as the examples from Debrecen confirm, they did not have the same rights and privileges as the full citizens. The inhabitants of Debrecen were divided into two groups in terms of legal rights: concives (fellow citizens) and lodgers. Before the eighteenth century the only ones entitled to 'civic rights' were those who paid the 'citizen tax' ( $p o l$ gártaksa); then, from the beginning of the eighteenth century the condition for acquiring the right was to own a house. Civic rights were not inheritable; they were only granted to widows until the end of their lives. Since civic rights were accompanied by a piece of land, over the course of early modern times magistrates of Debrecen were very careful to issue the right only to as many inhabitants as they could provide the appropriate size of field, meadow, pasture to. Citizens (in Debrecen given the Latin term civis) had a share in the city's forests in firewood and building timber. Only they could become guild members and participate in official elections. ${ }^{111}$ According to the estimates of István Rácz, at the beginning of the eighteenth century, out of a Debrecen population of more than ten thousand only one thousand people had civic rights, while their number at the end of the century may have been around two thousand to two thousand five hundred. 
Lodgers, who constituted the majority of the population, did not own a house but they might have had a smaller vineyard or plot of land. They only received brushwood from the forest, and they also had to pay a small amount of urban tax. ${ }^{112}$ According to Debrecen sources there were various ways of becoming a lodger. Poorer people moving to the city from another town; impoverished citizens; the widows of citizens who were not able to maintain their own home; local poor people unable to pay the citizen tax or to buy a house; people who could not be placed in the asylum for the poor (ispotály), or in the hospital, who were called 'domestic poor' in the eighteenth century: all these constituted the large group comprising the lodger population. ${ }^{113}$

In post-Ottoman Debrecen, which now enjoyed the rank of free royal city, the problems relating to a population lacking civic rights emerged with an unprecedented acuteness during the process of reorganizing urban life, increasing the institutionalization of social and other activities and last but not least living under the pressure of economic hardship. During Ottoman rule, it is known, the population of the city grew significantly, with people fleeing the destroyed villages obviously becoming lodgers. ${ }^{114}$ At this point, the only condition to taking them in was to inform the magistrate of their arrival. This, however, considering the chaotic times, rarely happened, and at this point the city council did not question for whom they were providing shelter. However, with the end of the Ottoman era and after earning the title of a free royal city, they tried to make the conditions of moving to the city and of becoming a lodger stricter.

These efforts were actually reactions to the decline of the economy of the city at the end of Ottoman rule and at the beginning of the eighteenth century. Industrial and trade activities in Debrecen decreased significantly in this period; the city no longer had the capacity to take on and support poorer immigrants. This was especially the case since the process of pauperization and the rising number of landless peasants (zsellér) had also begun in Debrecen: bankrupted local retailers and craftsmen were already multiplying the number of the poor. ${ }^{115}$

The magistracy, in addition to its rational purposes as regards the economical sustainability of the city, had its moral reasons as well in trying to regulate poverty by issuing a series of decrees during the seventeenth and eighteenth centuries. In January 1696, for instance, they issued the following ordinance relating to lodgers: "Landlords should only take in lodgers for whom a Juror has vouched and taken responsibility: if they 
come from elsewhere, they must have a good recommendation. Truants fleeing from one street or one house to another, who avoid payment and service, must not be taken in by anybody; one has to report such persons to the Juror. If a suspicious, sinful delinquent of ill repute is found at someone's home, those persons are violating their concivis duties, and the abetters should receive the same punishment as the culprit." The supervisors of the street's administrative and economic organization (tizházgazda) made it their duty to "frequently stroll the streets, at least twice a week, and to examine the kind of people who live there." The decrees were reissued in May. ${ }^{116}$

The civic citizen's oath recorded in the Matricula Civium (book of citizens) from 1707 also included such ordinances with relation to lodgers. The fourth point, for instance, was the following: "You may not take in as lodgers people who avoid service or payment, especially people of ill repute, sinners and delinquents; you should not hide them, and if you witness someone doing so in the city, you must report it." The fifth point required citizens "not to take in strangers as lodgers to your house beside your own servants without reporting that you have done so at the person's arrival and when the person leaves your house." 117

Among the lodgers there were quite a few who were domestic poor or beggars, who were accommodated by certain landlords out of Christian duty and in exchange for completing minor household tasks. It is worth mentioning that the late seventeenth and early eighteenth century saw numerous ordinances regulating the situation of the domestic poor added to regulations relating to lodgers. All this confirms the contemporary modification of the traditional care provided to poor people in the city.

The first 'inner' hospital (situated within the city) in Debrecen was established in 1529 by a citizen who offered his own house for this purpose. After the consolidation of Calvinism the Franciscans left the convent of Csapó Street and the magistrate moved the poor people here. The hospice stood here until 1704. The 'outer' hospital-located outside the city-was established around 1552. In 1705 the council shut down the inner shelter and relocated the resident poor to the hospice outside the city. This, after a connecting church was built next to it, became a congregation with its own ministry, and as Gábor Herpay observed, ${ }^{118}$ henceforth it was the responsibility of this establishment to handle the problems of the poor who were supposed to move outside the city. As the report addressed to the royal Chambers in 1698 shows, the hospital 
accepted people unfit for work, those with a physical or mental disability, and poor or impoverished people unable to make a living, and primarily those who were inhabitants of Debrecen. They completed various tasks, the men, for instance did stubbling, while the women did weaving work. The maintenance costs of the establishment were covered partly from donations, and partly from specified incomes-profit from the mills, the city land tithe for the poor, incomes from beer-shops, the price of strayed cattle, and two thirds of the cattle of people deceased without a will. The hospitals, however, did not have the capacity to take in all the poor citizens of the city: in 1698-1699 there were, for instance, only 40-50 inhabitants in the shelter. ${ }^{119}$ Until the end of the seventeenth century all this did not cause such a great problem as it did later, because until then the "hungry poor from the streets", that is, the domestic poor, had the right to beg at the church gates and at funerals. ${ }^{120}$

From the end of the seventeenth century, however, probably because the number of poor had so increased, the magistrate not only moved the hospice out of the city, but also tried to prohibit the poor from begging. An entire series of decrees was issued to this end. In 1695, for example, the following ordinances were issued about beggars: "those who are worthy of alms should go and join the others [in the shelter], and no one is allowed to knock on doors begging. If someone would like to give alms, he should take it to the public location." 121 This "public location" was the church, where the preachers had to announce the mendicants from the hospice once a month, and one could give donations only to them and only there. The ordinance was re-issued in 1696; then, in 1700 , they ordered once again that "the beggars are not to dwell and cry at the church gates, but to stay at their accommodation."122

It would seem, however, that these measures proved rather ineffective, for in 1720 they had to be repeated. This time, as the magistrate wrote, "the beggars flooded [the city]" and continued to beg from one house to another. The decree prohibited this once again, or allowed the exception of "those who are worthy and should be able to walk around without suspicion with a specific mark." This, nevertheless, entailed a strict investigation as a condition, both of the beggars and the lodgers: "thus, every mendicant has to be sent to the district supervisors in the City Hall for investigation. The population of the city has to be investigated house by house as well, to see what kind of lodgers there are. Suspicious persons should be escorted to the jurors dealing with them. And they themselves should stay vigilant." 123 
The fight against the city's poor also included measures which ordered the demolition of "huts, sheds and other useless houses". During the eighteenth century, the decree first issued in 1695 was repeatedly reissued, which again suggests that its implementation was not entirely efficient: "we order in relation to wanderers and huts that the huts dug in the streets be demolished; furthermore, that dilapidated housing, in which the derelicts avoiding payment and service hide, should be demolished as well. The district supervisors are also called upon to attend to those who arrive in the city and to report them. The landlords as well, to whom these people go, should report the fact; and should someone take in such a person, they should be punished." 124

We should also mention that it was around this time that the city also set out to regulate the Gypsy population. According to an ordinance of 1696, "the hiding derelict Gypsies living in huts and tents must be cleaned out of the city; from here on they are not only forbidden to live in the city, but are not even permitted to sleep here. Gypsies living in permanent housing and paying their taxes and sustaining other burdens are permitted to stay inside the city; nevertheless, they must not cheat other citizens by trading in horses. There shall be regulations which, if impinged, will result in them automatically being banished from the city." 125

The situation of the poor in Debrecen thus became very hard from the beginning of the eighteenth century. The shelter established outside the city was not able to accept the mass of humanity arriving from the city; meanwhile, the magistrate deprived these poor people of their traditionally most important instrument of livelihood, the right to go begging from house to house. It is worth noting that these regulations affected the people newly settling into the city more than the people originally from Debrecen. The former were not willingly accepted by the outside shelter, and the church donations were also only provided to the sheltered poor of Debrecen. The poor coming from elsewhere found themselves in a situation even more miserable than the locals.

The administrative measures, however, were not successful; mendicancy continued in the city, only under circumstances considered 'illegal'. We can justly presume that the campaign in Debrecen at the end of the seventeenth and at the beginning of the eighteenth centuries only intensified suspicions already existing due to the stereotype of the 'poor witch' against lodgers, the domestic poor, poor neighbors and against Gypsies, as we can presume by the few cases of Gypsy witches in the 
second half of the eighteenth century. Since the regulations made the landlords responsible for their lodgers and imposed a reporting obligation on them in cases where they discovered anyone leading a lifestyle violating the ordinances, the landlords, trying to avoid punishment, must have felt encouraged to report such persons. We should point out that moral considerations behind the regulations against lodgers and the poor may also have anticipated the development of witchcraft accusations. We have seen that in Debrecen the opinion of both the Calvinist religion and the magistracy associated numerous types of crime with witchcraft, and according to the witness testimonies of trials there were quite a few examples for such associations among the inhabitants.

From the perspective of the victims of the accused lodger and beggar appearing in witch trials we should recall the potential explanation proposed by Keith Thomas and Alan Macfarlane, since in many regards it seems to be applicable to the development of witchcraft accusations against the poor in Debrecen in the eighteenth century.

The citizens of seventeenth-century Debrecen, as well as the community of Elizabethan-era England, had accustomed themselves to give out alms, an act which was even required by their religion. Nevertheless, when in England under the influence of the establishment of a new, individualistic approach and in Debrecen as a result of the magistracy's campaign against the poor, the neighbors rejected those poor demanding assistance or denounced their lodgers, they had to face a severe moral problem. Considering that the religiously prescribed tradition of providing help and almsgiving was still a vivid part of their mindsets, the behavior required by the magistracy must have provoked a deep remorse and guilty conscience in them. They tried to escape this feeling by accusing the begging poor of witchcraft, ${ }^{126}$ since-according to Thomas's argument - it was not a sin to deny help to someone who had entered a pact with the Devil.

As the re-issued regulations confirm, the council of Debrecen was not really successful in achieving its goal: they were unable to cleanse the city of the unwanted elements through 'regulative measures'. Thus the witchcraft accusations against the poor served as a tool in this campaign. Let us look at a few examples.

The widow of Bálint Kis from Debrecen lived variously in the homes of three landlords in Mester Street prior to her trial in 1694. She was cognisant with medicinal herbs and also with several practices belonging to the category of love magic and magic for boosting agricultural prosperity. It appears, on the basis of the trial, that she wanted to 'pay' 
for her accommodation and to reinforce her status as a lodger with her magical skills. This, however, turned out to be a very dangerous option. At the home of Gergely Marjai she tried to heal his son with herbs, but was unsuccessful. Mrs. Marjai found Mrs. Kis in the courtyard one night, and in the morning she told the judges in shock that she had found straw ashes where Mrs. Kis had been sitting. The suspicions of the landlords were also confirmed by learning that a servant and a woman neighbor had also accused Mrs. Kis of bewitching their eyes; the servant had even come to their house for treatment. Marjai and his wife kicked the old woman out of their house shortly thereafter. She told her subsequent landlady, Mrs. Mihály Gulyás, that she used to have a lover when she was young, "who came from the sky". Mrs. Gulyás must have been informed about the bewitchments attributed to Mrs. Kis, and when she broke one of Mrs. Kis's pots, she was afraid that she might fall victim to her as well. As she related one week after the incident, "I heard a big rushing noise", and "a woman [Mrs. Kis] in green robes came out of the bush and squeezed me at the waist; I put my hands on her shoulder and asked, "Why are you so angry with me, dear friend..." She replied, "You know, the other day you broke my glazed pot." Mrs. Gulyás did not mention other damages she had suffered; apparently after this incident she chased her lodger away: "As soon as the pot incident took place, I no longer kept her in my house." Mrs. Kis tried to win over her next landlady, Mrs. István Dinnyés (who probably was already aware of her reputation in the street) by teaching her how to extract more milk from her cow and how to protect it from maleficium. She also gave advice to Mrs. Dinnyés's son on how to conquer girls he desired. Magical knowledge, however, was a double-edged sword: when several of her kin became ill, Mrs. Dinnyés found it easy to blame the bewitchment on her: "She called that person [Mrs. Kis] a witch to her face, saying she had eaten her son, her daughter and herself as well."

The woman lodger was eventually banished from Debrecen, because, as the judges claimed, "with her advice serving fornication and her use of prohibited instruments she was provoking scandal." 127

A poor woman, Judit Sarkadi, was brought to tribunal in 1720, in the year of one of the mendicant regulations. The charges against her were that "she was begging in a fraudulent way: when they only gave her bread, she started to threaten them, give me some more, or else you'll regret even the milk of your mother. Then in their houses one could hear a great pounding and all the pots and vessels fell out of their places." The maleficium narrative recorded in the regrettably very short trial 
document represents the typical situation of the denial of a favor and the consequent damages, which probably had some grounding in reality if one considers the ongoing campaign against the poor and the 'beggarwitch' scare.

The beggar woman should have been sentenced to be burnt according to the indictment, but she had not confessed anything during torture. We do not know what her verdict was. ${ }^{128}$

Kata Szabó, called "Healer Kata", was brought to trial in 1718. According to the witnesses she was often a guest at taverns and at merriments, and "young lads" often visited her. During the time of the trial she was already living in the home of her second landlord. Her first landlord, the slaughterer Péter Fodor from Péterfia Street, had kicked her out for her scandalous lifestyle and drunkenness. As a result, her magical knowledge was no protection to her, either. According to Mrs. Fodor, Miss Kata had threatened her husband for chasing her away from the house, "saying you will feel my incantation with many tears. And 2 weeks later he fell off his feet, and he has been miserable ever since." At her second landlord's, the bootmaker András Pap in Új Hatvan Street, she continued her lifestyle, falling far from the ideal of a 'God-fearing honest woman'. She tried to earn the trust of her landlady, as healers usually did, by showing her her body, which had allegedly been beaten by witches for her healing activities: "She lifted her skirt and the witness saw a blue bruise on her leg, and she said: It has been there for 3 days." The household of András Pap was often harassed by men visiting Miss Kata, and according to witnesses she also used to go home late and was often drunk and quarreled with the Pap family's servants. Kata Szabó incorporated exactly the type of lodger 'of ill repute' whom the city regulations expected to be reported. It is also noteworthy to see how many kinds of 'dangerous relations' appeared simultaneously in her case (as well): besides the landlord-lodger relation there were the tensions between healers and patients, and those between 'persons of ill repute' and 'honest Christians'.

After her witch trial she was beaten and banished from the city. ${ }^{129}$

Further research needs to be done in order to see how the situation of full citizens and their lodgers operated in other market towns of the county, and whether at the end of the Ottoman era and at the beginning of the eighteenth century there may have been similar efforts to regulate the situation of the poor similar to those of the Debrecen magistracy, charged with moral considerations. In any case it seems that the stereotype of the poor witch had its foundations in the county as well. 
Accordingly, among the people accused of witchcraft Mrs. Mátyás Fazekas from Hencida (1715) lived in a mud hut ${ }^{130}$; the cripple form Örvénd (Urvind), István Lengyel (1716) earned his living with his violin ${ }^{131}$; the council of Samson investigated the case of a 'wandering derelict' 'Romanian' (oláh) woman in $1746^{132}$; Mrs. Domján had to move at least three times before she was sued in Sarkad in 1744; and according to the 1715 trial of Mrs. Ferenc Cina from Bakonszeg "she could not survive in that poor condition if she did not have her knowledge."133 Mrs. Lippai who fled from Albis (Albiș), originally from Érsemjén (Șimian) $(1708)^{134}$; Mrs. István Harcsás from Berekböszörmény $(1715)^{135}$; Mrs. István Göbei from Hajdúbagos $(1723)^{136}$; Ferenc Nagy from Komádi $(1724)^{137}$; and Mrs. Mihály Kis from Ártánd $(1726)^{138}$ all earned their bread from sheep-farming. ${ }^{139}$ Moreover, the witchcraft accusations developing from lodger-landlord conflicts also occurred here and there in the market towns and villages of the county.

We know from the 1715 trial of Mrs. Miklós Kulcsár from Hegyközpályi (Paleu) that she had become poor, and "the village judges took the house in which Miklós Kulcsár lived by the order of the ispán, and gave it to someone who could better support himself." Mrs. Kulcsár may already have been under suspicion, because earlier her mother had been burnt as a witch. She had a reputation of having been, in an earlier period, irreconcilable with others as a landlady; several witnesses have described in detail how she had chased one of her lodgers from the house, and how she had 'bewitched' the lodger's cow as well. Mrs. Kulcsár did not take it lightly when they took her house away; she used to come back to quarrel with the new owners. The latter then attributed the illness of one of their cows to be the bewitchment of Mrs. Kulcsár. The Kulcsár family had to wander from one accommodation to the other, and they tried - with little success - to make a living with the help of their landlords and neighbors.

Mrs. Kulcsár probably lost her good reputation when her mother was burnt; the scandal about kicking a lodger out only made things worse. When she lost her own home, and needed the help of the already suspicious neighbors, her road to a witch trial was paved. According to the maleficium narratives her lodgers prevented her from taking her wheat to the mill; her neighbors refused to give her a bushel of wheat or a laundry tub, or to help her husband plough; and when any kind of damage happened to them, they attributed it to bewitchment on the part of the angry Mrs. Kulcsár. The type of conflict resulting from denying a favor 
to someone corresponds once again with the status and lifestyle of the accused witch.

We do not know the verdict of her trial. ${ }^{140}$

Behind the denial of a favor, help or cooperation in the discussed narratives, as we have seen, there often lies the conflict between the poorer and the wealthier population. In Debrecen this was integrated into the processes of regulating the settlement of newcomers to the city and of modifying the care provided for the poor. The maleficium narratives opposing lodgers and landlords (cives) represent certain forms of the problematic co-habitation and interactions between these two strata, which became increasingly tense, especially in Debrecen at the end of the Ottoman era and the beginning of the eighteenth century. Accusations of witchcraft, if my hypothesis based on the theories of Keith Thomas and Alan Macfarlane is right, helped the wealthier part of the population to rid themselves of these burdened relationships and to ease their guilty consciences for doing so. Thus it can be said that an accusation of witchcraft, itself a facilitator in executing administrative measures, helped in the establishment of a new urban order.

In this process, of which the above-discussed establishment and legitimation of public healthcare was also part, we should not however overestimate the weight of witchcraft accusations against the poor. On the one hand, poverty in itself was not a catalyst of witchcraft accusation: I could refer to numerous other trials from the judicial period of Debrecen in the two examined centuries in which beggars, lodgers and newly settled-in strangers were 'only' accused of theft, fornication, playing music without authorization, murder, etc., and not of witcheraft. On the other hand, the city's campaign against poverty at the beginning of the eighteenth century created circumstances which allowed it to rid itself of unwanted strangers, lodgers and beggars without accusing them of witchcraft: namely on the basis of the accusation of 'illegality'. This might explain why in the eighteenth century trials in Debrecen the accused poor or beggar witches - even though we cannot estimate their exact ratio-did not constitute a vast majority.

\section{Wealthy Witches of 'High' Status}

Extreme cases of accusations 'from below' against important town or village officials seemingly rarely occurred either in Debrecen, or in other parts of the county, although again I cannot give an exact percentage. I 
believe that these were rather isolated cases which, if better sources were available, could be interpreted in each individual situation. There were no greater social processes in the background, such as in the case of the campaign against the poor of Debrecen.

Mrs. Gergely Bagoly from Debrecen, who was considered by László Makkai to be the kin of a nobleman and a former judge, was punished for adultery rather than for witchcraft. ${ }^{141}$ The wife of Town councillor László Szücs was accused rather for healing and divination in 1631. ${ }^{142}$ These two cases, however, seem to contradict the hypothesis of Erik Midelfort, according to which the stereotype of the 'poor witch' was broken down in cases of mass accusations when the witchcraft accusation could basically reach anyone, and hence wealthier people of higher positions as well. ${ }^{143}$ Neither the case of Mrs. Bagoly nor that of Mrs. Szücs was related to a witch panic. And out of the further three cases involving wealthy, noble women of Bihar County, only one trial (the aforementioned trial of Ottomány) has surpassed the threshold regarding the number of accused, which, according to Brian Patrick Levack, is the margin for a panic-like witch-hunt.

In Nagykereki in 1724, in the suit against the wife of judge György Szabó, at least six other local 'witches' from other villages of the county were identified. Nevertheless, it is worth noticing that Mrs. György Szabó's primary trouble was with the 'German Captain' staying in Nagykereki. The reason for his discontent was probably not what the witnesses told, namely that one of his puppies had died because Mrs. Szabó had bewitched it; it was more likely that he had problems with his accommodation, and blamed the judge's family for it. In the Ottomány trial of the same year, which was the only incident of accusation in Bihar County that can be considered as a 'witch-craze', the wife of the judge Tamás Kerekes was accused of witchcraft alongside nine other persons. Mrs. Kerekes was also accused by two other witches of riding cats and people. The local notary registered her in the witch association he assembled as a 'pvt' (köz). ${ }^{144}$

There are no records of the verdicts passed on the two women, although it would be essential to know how the sedria decided in the case of 'witches' from the top of the social ladder.

Mrs. Mihály Panyolay (1765), the wife of the judge's brother in Kismarja, apparently arrived at a poorer neighborhood after moving from a Bihar village to the market town. The witnesses had stated that she could not even weave properly, and that she was an indulgent 
woman. One of her victims called her "Mrs. Karaffa", associating her with the notorious late seventeenth century imperial general, Antonio Caraffa, who ruthlessly imposed taxes: "in Bihar you had to carry the chest of poverty yourself, and you were looking for the key, opened the chest and left it empty... just go to Bihar, the people there will tell you what you have been; you acted like Caraffa, you tormented the poor." Another victim disparaged her with the following words: "you clear witch whore, just because your brother-in-law is the judge, I am not afraid to say it, if they are kin or friend to the judge, any petty rascal is allowed to come to Marja, no matter if they come from the Devil or from hell." The former victim considered it to have been a bewitchment by Mrs. Panyolay that the wind blew off the roof of her house, while the latter blamed her for the death of her goose. In order to display to the public that Mrs. Panyolay was a witch, they hung the goose at her window. Finally it was Mrs. Panyolay who sued the two victims for slander.

It would be interesting to know how the trial ended, but, again, the sources have not preserved the verdicts. ${ }^{145}$

We cannot draw general conclusions from the few cases of women of high social status accused of witchcraft. I only wish to draw attention to the fact already indicated by the above-discussed witch-victim relations of the examined territory: the stereotype of the poor witch was hardly an exclusive reality in the accusations.

I believe that the accusations of witchcraft are much more widespread on a social scale, and probably concerned primarily the middle strata who had somewhere to rise or fall down from, so that their relationship with their narrow environment (house, neighborhood, street, etc.) could become problematic, and thus, interpreting the events through the lens of witchcraft, the possibility arose that they could become witches or victims. As the previous cases show, witchcraft accusation nonetheless, did eventually reach a group with significant power, judges of considerable wealth. This did not necessarily require a panic-like witch-hunt, as supposed by Erik Midelfort, because incidental changes also occurred in their milieu, in their microenvironment-as we have seen in the case of Mrs. Panyolay, who moved into a poorer neighborhood in Kismarja, or in that of the quartered soldier and the judge's wife in Nagykereki-situations which could have contributed to the development of suspicion of witchcraft. 


\section{Hajdú Gentrr (Hajdúnemesek) and Serfs (Jobbágyok)}

The witch trials at the manor of Derecske in Bihar county are no different at first sight from any other trial of the region and of the time period. In the course of research, however, it transpired that the maleficium narratives often oppose the former hajdú gentry (bajdúnemes) and serfs (jobbágy), who alternately appeared as witches or victims.

These witchcraft accusations, based on status oppositions, can be interpreted if we observe the social processes of the age that they represent. At the end of the Ottoman era (1702) the Palatine Prince Paul Esterházy received 16 settlements of the western part of Bihar County as a pledge property, which he proceeded to organize into a manor. In 1745 the princely family obtained the perpetual donation of the manor. Thirteen of the settlements had gained hajdu privileges during the seventeenth century, from István Bocskay, Gábor Báthori, Gábor Bethlen and other Transylvanian princes. They only owed military service to the princes, and they had their own municipality and the right to freely elect their judges. Their judicial cases were handled by the county court (sedria). ${ }^{146}$

At the end of Ottoman rule, however, neither the Royal Chamber nor the new seigneur Esterházy acknowledged their liberties. In 1700, in Vienna, it was declared that the hajdu towns "were bound to pay the tithe and other manorial allowances and taxes like any other subjects did." The Chamber and Esterházy deprived those settlements of the plains annexed to their territories during Ottoman rule. ${ }^{147}$ The eighteenth century censuses registered the population of these settlementsignoring their former privileges-as serfs and taxpayers, and they also started to settle a population of serfs into the hajdu settlements, which had been closed military communities during the Ottoman times. ${ }^{148}$

The manorial administration established at the beginning of the eighteenth century increasingly interfered with the free election of judges, and besides limiting judicial authority the provisors also appointed their own delegates to lead the council of the settlements. ${ }^{149}$ The lord wished to extend the jurisdiction of the manorial court provided with jus gladii to the serfs and like wise to the former hajdu gentry. His goal was obviously to eliminate all differences regarding the legal status of the people living on his land; he wished to see serfs who uniformly paid taxes and were subject to the manorial court's jurisdiction. The only concession he made was that he periodically redefined in contracts the obligations 
of the latter. It took, however, decades of back-and-forth negotiations until the hajdu gentry of the Derecske manor were willing to accept even this fairly advantageous contractual relationship as serfs. The period from which we have information of the witch trials of the hajdu settlements was therefore overloaded with multilateral conflicts: animosities between lords and hajdú gentry, hajdú gentry and serfs, lord and county.

We should point out two important 'alliances of interest': on the one side between the serfs and the lord (and the manorial administration), and on the other between the hajdu gentry and the county. Over the course of the eighteenth century the former nobles refused on several occasions the payment of the seigneurial tax and obstructed the census ordered by the administrators. This is what happened, for instance, in 1726, when the hajdu settlements jointly declared "that their inhabitants are free individuals who have the right to move freely, therefore they do not want to be included in the census, because it would entail feudal burdens." They liked to mention proudly that their first seigneur, Palatine Paul Esterházy, had addressed them as "your gracious lords". ${ }^{150}$ In 1745 , when the Esterházy family obtained the perpetual rights to the manor, they joined forces once again and contradicted the inauguration of the lord. All this, however, did not change the situation. They turned to the Chamber of Szepes 2 years later to no avail when they petitioned to redeem themselves: their request was denied. After the Urbarium agreement they took their case to trial once again, but they were not able to reclaim their liberties then, or ever again. ${ }^{151}$

Their fight for their privileges also included the repudiation of the manorial court's jurisdiction over them referring to themselves as "noble persons". In 1703 they requested the Prince that "our old law not be taken away from us, let us continue to live under it." 152 Since the Prince, however, did not fulfil their request either then or later, the hajdu gentry consequently concealed their legal affairs from the manorial provisors and, according to their old habit, turned to the county's vicecomes (deputy county judge, alispan) and the sedria. At the beginning of the century they found in the person of the deputy comes György Komáromi Csipkés an influential advocate for their cause from the ranks of the county authorities, who were anyhow reluctant to acknowledge a new, rival legal authority with the right to order capital punishment, such as was the Esterházy manorial court.

The fact that witch trials from hajdu settlements were tried (with one late exception) by the sedria can therefore be explained by its specific 
political background. The tendency, especially under the presidency of Komáromi Csipkés, was that the sedria's decisions apparently served the interests of the hajdú gentry.

By refusing to pay taxes to their lord, the hajdu gentry were indirectly augmenting the burdens on the-usually recently settled-serfs living in their settlements, since they had to pay more as a result. The 'poor' of these settlements brought complaints to the manorial officials, and mentioned other instances of domination: the operating of a small tavern, denying serfs the rights of property, not acknowledging "the staff of the peasant judge" (parasztbiró bottya), wrongfully extending their properties and lands, etc. In István Szendrey's view the serfs were far more opposed to the privileges of the nobles than was the lord. The latter, apparently, even exploited the discontentment of the serfs against the nobles: he encouraged the serfs to formulate their complaints in writing, stating how they had been domineered, so that later he could turn these letters of complaint against the hajdú gentry. ${ }^{153}$

The witch trials of Derecske manor originated in a very tense atmosphere, and even though the source material cannot be considered fully exploited, especially from the perspective of witch trials, it is still noteworthy to point out certain phenomena.

The witch trials of former hajdu towns provide numerous examples of accusations from both below and above; in several cases we can suspect or prove that gentry-serf conflicts lay in the background. We can presume that the nobles defending their privileges tried to get rid of certain recently settled serfs, for which, however, they had very little means. The trials conducted at the county's sedria-including witch trials-perhaps served as the best means to attain their goal. (The lord's sympathies lay with the serfs; his manorial court probably would not have supported the suing hajdú gentry either in a witch trial or any other legal proceeding.) About the displacement of serfs, however, the county court, who supported the hajdú gentry could not decide unless they had compelling reasons, since the serfs belonged to the manor. The hajdu gentry must have recognized a compelling reason in witchcraft accusations.

Obviously, this 'recognition' did not only occur when the Derecske manor was constituted. The hajdu nobles and the counter-accusing serfs built on formerly existing patterns when accusing each other of witchcraft. The organization of the manor and consequently the enforcement of the settling of serfs in the former hajdu settlements, however, created new conflicts which made it possible for witchcraft accusations to 
become an instrument of political fights. Even though the maleficium narratives do not mention this aspect, I still believe it is true. Let us look at some examples.

In 1699 the magistracy of Derecske led investigations surrounding a Gypsy woman, the wife of the voivode Miklós, a weaver woman, Mrs. Nagy, and Mrs. Márton Virágos, who had all moved to the hajdú gentry market town from Balmazújváros, thus increasing the number of unwanted serfs there. Witnesses were also heard against a local inhabitant, Mrs. Máté Tavasz, who lived in poverty. The primary accusation against them was that "they have eaten the children of the judge", who was most probably a member of the former hajdú gentry. Mrs. Máté Tavasz, when she was captured, started to make counter-accusations: accusing a member of a local noble family, Mrs. András Szabó, ${ }^{154}$ of witchcraft: "See... they capture the poor [woman], and Mrs. András Szabó, who is also a devil like us, she is not captured... she rides a black cat with slit ears." This trial evokes a stage of animosities between hajdu gentry and serfs preceding the establishment of the manor, when being a stranger and a settler was more incriminating for the accused than their status of serfdom (not yet associated with political aspects). Nonetheless, in the little-known conflict between the judge and Mrs. Máté Tavasz, the pattern of mutual witchcraft accusation, which later led to the proliferation of accusations, was already present. We have no knowledge of the outcome of the trial: documents have remained only in fragments. ${ }^{155}$

It was in 1714, after the establishment of the manor and now in a period of political conflict, that accusations were made against two women serfs. Mrs. György Borbély was suspected of having 'bewitched' the daughter of the juror János Dobai who, judging from his rank, was probably a hajdú noble. According to the narrative, Mrs. Borbély had asked for some pears, but had been refused them. The other woman, Mrs. Péter Juhos Kis, had been accused of 'torturing' a member of the bajdu gentry Tarsoly family. The cases of the two women were tried by the sedria, and they were both sentenced to take a cleansing oath. The documents unfortunately do not mention whether the oath was successful. ${ }^{156}$

In 1723, the hajdú gentry from Hajdúbagos were able to rid themselves of two women serfs. They also sued a third one, but her verdict is unknown. The accusations all began at the house of the hajdu nobleman, István Szarvadi. Szarvadi had accepted the shepherd Mrs. István Göbei as lodger. According to the victim, Mrs. Göbei had once threatened him, 
saying "your child will regret it... his two arms will lose bones." Mrs. Göbei was looked upon as a witch by several of her landlords. Among other things, she had 'bewitched' a maid of the Pap family, (also from the hajdu gentry), and threatened the family when they hired her husband to draw water but would not pay for his service right away. Several witnesses, including the hajdu gentry woman Erzsébet Kodormány, stated in their testimonies that the shepherd woman was 'aware of' her evil doings. According to Erzsébet she once told her: "it is time for me to go, because I have done enough good and bad, my ass has licked many thresholds." Eventually, the sedria banished her not only from Hajdúbagos, but also from the entire county. ${ }^{157}$

The mutually accusing serfs probably also saw in witchcraft accusation an opportune means to liberate them from the hajdu gentry, who were often domineering in defending their old rights. They had little chance of attaining their goal, however, since trials against accused hajdu were conducted in front of the county court, which supported them, as we shall see in the following examples.

The cases of the hajdú noblewomen Mrs. János Zuh and Mrs. Pál Tóth from Szalonta (Salonta) ${ }^{158}$ and Mrs. Zuh's mother, Mrs. Mihály László, were tried by the sedria in 1717. Mrs. Zuh, in addition to her noble rank, was probably a wealthy woman; we hear she had a servant, a miller lodger, and a hired shepherd. Despite her background, her neighbors explained her wealth by the fact that she possessed magical skills. Allegedly, "she could bewitch the cows at milking" with her special grease. One of the witnesses stated she had heard from Mrs. Zuh's daughter that "my mother ground the [caul of the cow] and fed it to the cows mixed with bran, that is how our milk is so buttery."

Mrs. Zuh was probably denounced by the serfs Mihály Lajos and his wife. We do not know the original cause of their conflict beyond the reasons Mrs. Lajos named in her narrative of the bewitchment: she had hit one of Mrs. Zuh's hens and one of her geese. Mrs. Lajos and her servant accused the noblewoman of maleficium. Mrs. Lajos tried to prove to the sedria that Mrs. Zuh had come to her with another person during the night, and "tramped on her heavily".

Differences between the testimonies of hajdú gentry and serf witnesses related to certain witchcraft-beliefs Mrs. Zuh was accused of are conspicuous. Those of her acquaintances who supported her-the members of other noble families such as the Tóth, Madas and Oláh families ${ }^{159}$ — said, for instance, that the reason Mrs. Zuh's finger had once 
been bandaged was because it had a boil on it. The servant of Mihály Lajos, however, said at the tribunal that Mrs. Zuh's injury was due to the incident when one night she appeared in front of her as a witch: "As she attacked the witness, Mrs. János Zuh grabbed the witness' throat and started to strangle her, one of her fingers got stuck in the witness's mouth, who chewed on it". And to confirm her assertion she referred to the testimony of Mihály Lajos: "I heard the next day from my master that Mrs. János Zuh's finger was bandaged."160 Mrs. Zuh's herdsman also accused her of wanting to poison him with pogácsa (traditional Hungarian pastry), and a lodger also raised accusations claiming that, accompanied by two other persons, after their fight she had wanted to slit his child's throat.

The hajdú gentry testifying in favor of Mrs. Zuh also said that her dog had once become rabid and run out of the village. According to the people testifying against her, it was Mrs. Zuh herself who had run that time like a dog. This is what the Gypsies chasing the dog testified to. Voivode Ádám said that "I could not run faster than the dog, I have never ran as fast as that day, a hundred-Forint racehorse could not keep up with me, there was no thorny bush or meadow that I could not cross... if they hadn't killed [the dog] I would still be running." 161

The noblewoman Mrs. Pál Tóth also got involved in a conflict with the Lajos family. She "kept" one of the Lajos's daughters at her house, and they suspected that she would bewitch her so that she could never have children. According to Mrs. Lajos, Mrs. Tóth used to "visit her" in the night with Mrs. Zuh. In her testimony she stated: "Mrs. Pál Tóth told the witness that she had suffered a lot because of her, but that sooner or later she would die by her hands."162

Mrs. Pál Tóth was sentenced to take an easily performable cleansing oath. The mother of Mrs. Zuh, Mrs. Mihály László, of whom the trial revealed practically nothing, was acquitted. It is hardly likely that Mrs. János Zuh was convicted as well, since she was able to find 17 witnesses testifying in her favor, including several hajdú gentry.

Despite the fact that the maleficium narratives do not enter into an explicit 'political' discourse, I believe that lying in the background of the witchcraft accusations of the Derecske manor we find a decidedly political opposition between hajdu gentry and serfs. The witchcraft accusations raised by hajdú nobles against serfs were meant to defend an ancient order based on their privileges. They belong to a series of desperate efforts which sought until the end of the eighteenth century to 
regain the privileges of the hajdu gentry. The counter-accusations by the serfs, on the other hand, had an inverse effect: they favored the manorial system supporting them; that is, the establishment of a new order.

The problem surrounding the social tensions within the Derecske manor is inseparable from social historical events in hajdú gentry towns, now integrated into a 'Hajdú district' in 1876-Szoboszló, Böszörmény, Dorog, etc. - as well as from the events of seventeenth- and eighteenthcentury witch-hunts in these towns. However, as this topic has been but barely researched; I cannot go into a more detailed analysis here.

The primary conclusion of this study is that the scapegoating efforts manifesting in the form of witchcraft accusations (subsiding during the times of war and intensifying during natural disasters) have a general pattern which is applicable everywhere. Witchcraft accusations in the region of our study cannot be described alone within the framework either of the tensions between the poor and their environment emphasized by Keith Thomas and Alan Macfarlane, or the ambiguous relations between the specialists of magic and their environment, as suggested by Richard Horsley and others. I also do not find entirely justified the hypothesis represented by Richard Horsley, and applied to Hungarian circumstances by Gábor Klaniczay, according to which "During the explosion of a witch-panic, accusations run along the lines of social or cultural tensions within the communities; but in the course of long-term, regular, but not (or rarely) excessive witch-hunting, as was the case in Hungary, the majority of the victims are the people who possess some kind of magical expertise." 163 On the basis of the overview it seems as if, in the region of our study, over the course of a long-term and systematic witch-hunting period the foundations of most accusations were actually the social and cultural tensions within the community; there was no need to have, say, 50 witches in order to formulate this issue in the form of a witchcraft accusation. As for the 'witch types', I also believe that we can only discuss them as far as the implications of the two groups of maleficium narratives established by Éva Pócs ${ }^{164}$ and also observed in the region of my research might suggest it: the witch prototype construed on the basis of conflicts stemming from situations of everyday cohabitation, which constituted the vast majority of the cases, and the witches fulfilling the role of a communal scapegoat and the target of everybody who represented the minority in the cases.

This, however, is what makes the research of witchcraft accusation interesting. It is not the figure of the witch and the related beliefs that 
deserve attention, but the dangerous relations on the foundation of which the witchcraft accusations were created. These relations, in my opinion, were always shaped by the given economical-social-cultural configurations. In Debrecen, for instance, the lodger-landlord and the beggar/poor-rich conflict was much more present than in the county. The accusations of moral and common offenses weighed a lot more in the city than in other parts of the region. The conflicts between the specialists of positive magic and their environment also represented a more serious problem in the city when compared to the county. Meanwhile, in the privileged settlements of the county the accusations stemmed more often from tensions due to status oppositions, as in Debrecen. In the background of these, as we have seen in the case of the Derecske manor, there lay social problems characteristic of the given settlement and region in a given period.

All these conclusions take us to another, not particularly different second broad conclusion derived from what we have discussed above, namely to the position that we must handle stereotypes with precaution, whether they are established by preachers, witnesses of witch trials or historians and anthropologists. The image of the 'poor old witch', professed by all of the above, does not apply to the entirety of the witch-hunt in the examined region, as we have seen. It might apply to the case of the supernatural witch-generally an imagined belief-figure-but to the everyday or social witch, characteristic of most of the accusations, apparently it is not applicable. The latter are scattered across a much wider scale which I will discuss below.

We have to be equally cautious with assertions relating to the function of witchcraft accusation. As Victor Turner has pointed out in his previously mentioned critique, the anthropologists of the 1950s argued, besides presuming in the context of functionalism that societies are static, that witchcraft accusations had an establishing, almost conserving effect on the order of society; that is, of the community. Turner himself, alongside Thomas and Macfarlane, emphasized the opposite side of social changes, claiming that, on the contrary, the accusations were preparing the ground for something new. The study of everyday dangerous relations in our region is somewhere midway; I can simultaneously support both opinions.

In the typical conflict situations of the region and period of my study the orientation of witchcraft accusations can be modelled in the following way. Against women accused of moral and other offenses, and on 
behalf of the hajdu gentry, against serfs, the witchcraft accusation can be considered an instrument to protect traditional values, a force of law enforcement on one hand. On the other hand, against the representatives of traditional positive magic, or against the beggars and lodgers of Debrecen, and, on behalf of the serfs of Derecske, against gentry the accusations can be interpreted as an instrument to dissolve the old order, and to prepare a new mentality. Nonetheless, taking all this into consideration I believe that it is not the witchcraft accusation itself, but its given social context which determines the function of the accusation. And why should a researcher of witch-hunting expect only one single function and one single context? If witchcraft accusation arose in problematic sectors of social and human cohabitation, or is a representation of it, we have no reason to presume that this cohabitation deteriorated in one aspect only, in one single sector, and that witcheraft accusation had an effect in only one direction.

I must stress once more that in my description above I have only modelled the two functions of the witchcraft accusations. I did not intend to qualify them in terms of an idea of social 'development': in mentioning forces of law enforcement and of order dissolution I did not intend to formulate a judgment.

The few trials, the abundant archival sources of which have allowed me to perform 'deep drillings', have provided a third conclusion. After discarding the generally accepted schemes and stereotypes, for the interpretation of witchcraft accusations it is not enough for the researcher to show the dangerous relations within the given community in a given period and given social context. A trial that seemingly fits into such a category still reveals a specific, individual micro-context, which constitutes the real framework of the accusations.

This is where, in my opinion, the warning of the much-cited analysis by Jeanne Favret-Saada concerning the questionable authenticity of maleficium narratives is the most applicable. I believe that these narratives, and the types of conflicts and bewitchments they tell, operate as an interpretive scheme in which any realistic event can be substituted, or can be made to correspond to a social micro-context generating animosities. It is probably very likely that during the substitution process the real context and the real events-obeying the logic of maleficium narratives-were more or less modified and transformed; they did not, however lose all contact with reality. We have seen several examples in which the majority of the accused were placed under the framework of conflicts 
by the victims, which were/might have been indeed connected to the lifestyles and social interactions of the former. I find it, however, absolutely impossible to interpret and explain the micro-context of the actual witchcraft accusation only on the basis of maleficium narratives. The results of my 'deep drillings' have confirmed the hypothesis that the victims did not necessarily mention in front of the tribunal the true reasons why they hated this or that individual, and why they considered themselves to be their victims. My research in Debrecen provided numerous complementary data which were not even mentioned in the witch trials per se: on the past of the accused, pervious legal incidents or informal conflicts of the accused, their financial and social status, their direct home and neighborhood, etc.

Accordingly, we should only 'believe' the maleficium narratives if we are able to compare them with other types of texts and sources. It is the result of such a comparison which has brought me to think that the maleficium narratives of Debrecen, when they represent the dissolution of certain social norms (related to specialists of magic, or the poor, beggars), refer to the same thing that was happening on a sociological level in the city's social and cultural history, even if on a different-symbolic-level. They speak of the rearrangements after the Ottoman era: the changes in the direction of centralization and institutionalization, the new social and cultural exclusion and the differences arising from these changes. They also show us certain older norms, represented, for example, by the 'healing women', or the traditional support of the begging poor, norms which did not easily succumb to the new order.

This is basically the situation with the maleficium narratives of the Derecske manor: the narratives place in opposition serfs and hajdu gentry as witches and victims who, as we have seen, were already opponents in another fight which had a political background. The stake of the conflict, nonetheless, was not a wounded foot or a cow giving bloody milk, but - in this case again-to work out a new order after Ottoman rule: centralization and the leveling of old group identities, or regionalism and the preservation of the latter.

If I had to give a general answer to the question of what the maleficium narratives 'are about', my answer would be: they are about social dynamics. Besides representing certain changes within a given community, naturally according to their own, specific 'witchcraft-related' encoding, they also displayed what the norms were. The protection of old rules and customs clashed with their intention to introduce new forms. 
On the basis of certain more or less discovered micro-contexts of the accusations I would like to point out that the probability of witchcraft accusations occurring was higher in situations which were overloaded with economical-social-cultural conflicts in which the tensions were multilaterally concentrated. I would like to refer to only two previous examples. In the case of Mrs. Márton Rácz from Debrecen, accused in 1725, the witch-victim relation included the following oppositions at the same time: stranger-local, neighbor-neighbor, richpoor, health-disease, 'offense of ill repute'-'Christian life', while Mrs. András Bartha, a woman who specialized in recognizing healers and witches living in the vicinity, also played a big role. In a 1730 trial in Debrecen, when five accused, including two healer women (Mrs. Mihály Jóna and Mrs. András Nagy) were brought before a tribunal, all the above-mentioned oppositions were displayed, and we could add problems occurring in the relations between 'illegitimate' healer'illegitimate' healer, 'illegitimate' healing-'legal' healing, and healerpatient relations to the list.

Witchcraft accusations presumably developed more often in situations in which the dangerous relations within a given community appeared cumulatively in the micro-context of certain structured groupshouse, neighborhood, district, street, clientele, guild, region, and so on. Contexts where-to quote John Putnam Demos-"life was really dense". ${ }^{165}$

Finally, thinking with the logic of witchcraft accusations several conclusions can be drawn which, though hypothetical, yet constitute a sort of model which helped to interpret many characteristics of the witchhunting of my study. If witchcraft accusation is an act of scapegoating stemming from the deterioration of interpersonal relations, then certain forms of social interactions are needed. For this interaction a certain spatial and social proximity is necessary. Spatial proximity is well illustrated by rival healers crossing each other's interests, the lodger-landlord, neighbor-neighbor oppositions and the general particularities of bewitchment cases, namely that the witches were not from a distant town, but lived in the direct vicinity of the victims. Social proximity means two things. On the one hand, that the social and financial situation of the victim and the witch are not so different from one another. This difference may include the disparities between the (houseless) lodger and the (house owner) landlord, or the gentry and the serfs; the differences between extreme poles, such as the wandering Gypsy/Romanian 
mountain shepherd/poor beggar versus a nobleman/noble judge/priest, however, could be included to a much lesser extent.

In terms of status and financial situation, as I have previously proposed, the people involved in witchcraft come primarily from the middle strata (which cannot be better specified according to my current knowledge). The reason is simple. Only those individuals can become victims who have something to lose from their material or symbolic capital but whose status/wealth/capital is not so substantial as not to feel the 'pain' of the loss. The witch was always someone who 'stood out' from the micro-community upwards or downwards, yet was not different to the point of separating from the community, since it would have brought an end to the interaction which eventually made him or her a witch.

Maybe this context also confirms my calculations concerning the age and marital status of witches and victims; as we have seen, the centre of witchcraft accusation was constituted by the most active stratum of the community: middle-aged married couples. These presumably had enough symbolic and material capital which they could lose, but not as much capital for the loss to be painless. On the other hand, as the most active people in the prime of their lives they had the greatest opportunity to stand out from others, and they were obviously the ones to compete the most with one another. Furthermore, being the most active social layer, they could potentially have constituted a group of people having a 'dense life', and it could have been the case that dangerous relations occurred most cumulatively with them.

Meanwhile, social proximity also meant that those who lacked such proximity did not participate in the interaction and so could become neither victim nor witch. Probably this is the explanation for why there were so few Gypsies and Romanians or Catholics among the victims and accused witches of Bihar County.

The witchcraft model discussed relies partly on my concrete research results, but is partly a collection of mere hypotheses and deductions. The reason I have considered it worthy of discussion is that it constituted a most consequent and coherent scheme, which with the proper modifications and after having applied it to interpret the witch-hunting of the region and period of my study, may be helpful in approaching similar issues of other regions and other periods of time. 


\section{Abbreviations}

BA KLEIO-printout: A printed end-result of quantitative analyses made by means of the software KLEIO, preserved in the "Archive of Witchcraft" (Boszorkánybit Archivum), a manuscript database containing files from the fieldwork and archival research of Hungarian scholars, Institute of Ethnology, Hungarian Academy of Sciences, Budapest.

HBmL: Hajdú-Bihar megyei Levéltár [Archives of Hajdú-Bihar County], Debrecen.

HBmLf: Debrecen város magisztrátusának jegyzökönyvei [Protocols of the magistrate of the city of Debrecen], A Hajdu-Bihar megyei Levéltár forráskiadványai [Publications of the Archives of Hajdú-Bihar County], Debrecen, 1982-1987.

TtREL: Tiszántúli Református Egyházkerület Levéltára [Archives of the Diocese of the Reformed Church], Debrecen.

\section{Notes}

1. Edward Evan Evans-Pritchard, 'Witchcraft', Africa, 8, (1935), 417-22; id., Witchcraft, Oracles and Magic Among the Azande (Oxford: Oxford UP, 1937).

2. Mary Douglas, 'Introduction: 30 years after Witchcraft, Oracles and Magic', in ead., Witchcraft Confessions and Accusations (London: Tavistock, 1970), xiii-xxxxviii; Max Marwick, 'Witchcraft as a social strain-gauge', in id. (ed.), Witchcraft and Sorcery. Selected Readings, (Harmondsworth and Middlesex: Penguin Books, 1982 [Harmondsworth: Penguin Books, 1970]), 300-313; id., 'The social context of Cewa witch-beliefs', Africa, 22 (1952), 120-135, 215-233.

3. Victor Witter Turner, 'Witchcraft and Sorcery; Taxonomy versus Dynamics', Africa, 34 (1964), 314-325.

4. Keith Thomas, Religion and the Decline of Magic. Studies in popular beliefs in sixteenth- and seventeenth-century England (Harmondsworth: Penguin, 1978), [London: Weidenfeld and Nicolson, 1971]. 
5. Alan Macfarlane, Witchcraft in Tudor and Stuart England. A Regional and Comparative Study (New York and Evanston: Harper \& Row, 1970).

6. William Monter, Witchcraft in France and Switzerland. The Borderlands during the Reformation (Ithaca and London: Cambridge UP, 1976); H.C. Erik Midelfort, Witch Hunting in Southwestern Germany, 15621684: The Social and Intellectual Foundations (Stanford: Stanford UP, 1972); John Putnam Demos, Entertaining Satan. Witchcraft and the Culture of Early New England (Oxford and New York: Oxford UP, 1982).

7. Jeanne Favret-Saada, Les mots, la mort, les sorts. La sorcellerie dans le Bocage (Paris: Gallimard, 1977); ead., Jeanne Favret-Saada, Corps pour corps. Enquête sur la sorcellerie dans le Bocage (Paris: Gallimard, 1981).

8. Andor Komáromy (ed.), Magyarországi boszorkányperek oklevéltára [Source-book of Hungarian witch trials] (Budapest: MTA, 1910), 168-171.

9. Komáromy, Magyarországi boszorkányperek, 308-12.

10. Ferenc Schram (ed.), Magyarországi boszorkányperek, 1526-1768, I-II. [Witch trials in Hungary] (Budapest: Akadémiai, 1983 [1970]), I. 90-96.

11. Ibid., I. 78-80 and Komáromy, Magyarországi boszorkányperek, 271.

12. Ibid., 439-447.

13. Macfarlane, Witchcraft in Tudor, 199; Brian P. Levack, The Witch-Hunt in Early Modern Europe (London and New York: Longman, 1987), 137; Robert Muchembled, Culture populaire et culture des élites dans la France moderne (XVe-XVIIIe siècle) (Paris: Flammarion, 1978), 222; Monter, Witchcraft in France, 136.

14. Macfarlane, Witchcraft in Tudor, 159; Demos, Entertaining Satan, 77; Monter, Witchcraft in France, 136. (In this case the percentage ratio is my own calculation: I. Sz. K.).

15. Demos, Entertaining Satan, 76-77.

16. Mátyás Nógrádi, Lelki Probakő [Spiritual touchstone] (Debrecen, 1651); cf. Károly Szabó, Régi Magyar Könyvtár. Az 1531-1711. megjelent magyar nyomtatványok könyvészeti kézikönype [Old Hungarian Library. Bibliographic handbook of prints published in Hungary] (Budapest: MTA, 1879), (hereafter referred to as RMK), I, 845.

17. György Komáromi Csipkés, Igaz Hit [The true faith] (RMK I. 1042) (Szeben, 1666), 248.

18. Gáspár Decsi, Az utolso üdöben eginehani regnalo bünökröl [On some sins reigning in latest times] (RMK I. 189) (Debrecen, 1582), B3, C.

19. Komáromi Csipkés, Igaz Hit, 248.

20. Macfarlane, Witchcraft in Tudor, 159; Demos, Entertaining Satan, 76-77, Monter, Witchcraft in France, 135-139. 
21. Demos, Entertaining Satan, 79.

22. Komáromy, Magyarországi boszorkányperek, 363-364; HBmL, IV. A. 1018/g 25. No. 5; and József Bessenyei (ed.), A magyarországi boszorkányság forrásai I. [Sources of witchcraft in Hungary] (Budapest: Balassi, 1997), 374-388; Komáromy, Magyarországi boszorkányperek, 278-279.

23. Ibid., 363-364.

24. Schram, Magyarországi boszorkányperek, I. 115-116.

25. Ibid., 67-71.

26. Komáromy, Magyarországi boszorkányperek, 439-447.

27. Schram, Magyarországi boszorkányperek, 67-71.

28. Komáromy, Magyarországi boszorkányperek, 193-196.

29. HBmL, IV.A. 1011/a, vol. 23: 20 September 1694.

30. Komáromy, Magyarországi boszorkányperek, 194, 195.

31. Tized (meaning 'tenth') was an administrative unit in early modern Hungarian towns comprising ten households.

32. Nyilas (meaning 'arrow') was a medieval and early modern unit of measurement of land.

33. HBmL, IV.A. 1011/t, Censuses, vol. 3: Censuses by streets, 1728 and 1730 .

34. Komáromy, Magyarországi boszorkányperek, 363-364; HBmL, IV. A. 1018/g 25. No. 5; and Bessenyei, A magyarországi boszorkányság, I. 374-388.

35. Keith Thomas, Religion, 677.

36. Richard A. Horsley, 'Who Were the Witches? The Social Roles of the Accused in the European Witch Trials', The Journal of Interdisciplinary History, 9 (1979), 689-711.

37. Ibid., 703.

38. Schram, Magyarországi boszorkányperek, III. 69-76; Ágnes R. Várkonyi, 'Közgyógyítás és boszorkányhit. Mária Terézia boszorkánypereket beszüntető törvényének újragondolásához' [Public healthcare and witch beliefs. For a rethinking of the legislation of Maria Theresa abolishing witch trials], Ethnographia, 101 (1990), 384-437.

39. Komáromy, Magyarországi boszorkányperek, 103.

40. Ibid., 101.

41. Ibid., 170-173.

42. Ibid., 265-267.

43. Ibid., 272-273.

44. Ibid., 288.

45. Ibid., 358 .

46. Ibid., 428-; HBmL, IV. A. 1018/g. 25. No. 7 and Bessenyei, A magyarországi boszorkányság, I. 401-417. 
47. HBmL, IV. A. 1011/a 36, 277, 292; Bessenyei, A magyarországi boszorkányság, I. 433-434.

48. HBmL, IV. A. 1011/a 36, 292-293; Bessenyei, A magyarországi boszorkányság, I. 434-435.

49. HBmL, IV. A. $1011 /$ a 38, 245.

50. BA KLEIO-printout: "Illnesses" (Debrecen).

51. Ibid.

52. Komáromy, Magyarországi boszorkányperek, 695-708.

53. HBmL, IV. A. $1011 /$ a 42, 433.

54. Girispán, meaning rézrozsda (copper rost)—cf. A magyar nyelv történeti etimológiai szótára [Historical-etymological dictionary of the Hungarian language] 1. A-GY (Budapest: Akadémiai, 1967).

55. Komáromy, Magyarországi boszorkányperek, 428-429 és HBmL, IV. A. 1018/g 25. No. 7; and Bessenyei, A magyarországi boszorkányság, I. $401-417$.

56. Komáromy, Magyarországi boszorkányperek, 152-157.

57. Ibid., 162-168.

58. Ibid., 193-196.

59. Ibid., 265-267.

60. Ibid., 282-283; and HBmL, IV. A. 1018/d 1, 33, 368; Bessenyei, A magyarországi boszorkányság, I. 368-371.

61. See Komáromy, Magyarországi boszorkányperek, 428-429; HBmL, IV. A. 1018/g 25. No. 7; Bessenyei, A magyarországi boszorkányság, I. $401-417$.

62. HBmLf, 1983, 3, 26.

63. Ibid., 3, 72 .

64. Ibid., 3, 7, 38 .

65. Schram, Magyarországi boszorkányperek, I. 124-128.

66. Komáromy, Magyarországi boszorkányperek, 162-168.

67. Ibid., 157-161.

68. Ibid., 168-171.

69. Ibid., 157-161, 168-171.

70. BA KLEIO printout: “Conflicts” (Debrecen).

71. Komáromy, Magyarországi boszorkányperek, 428-429; HBmL, IV. A. 1018/g 25. No. 7; Bessenyei, A magyarországi boszorkányság, I. 401-417.

72. Komáromy, Magyarországi boszorkányperek, 354-363; HBmL, IV. A. 1018/g 25. No. 2; Bessenyei, A magyarországi boszorkányság, I. 389-400.

73. For Mrs. Márton Rácz see Komáromy, Magyarországi boszorkányperek, 363-364; HBmL, IV. A. 1018/g 25. No. 5; Bessenyei, A magyarországi boszorkányság, I. 374-388; for Mrs. Mihály Kis see Komáromy, 
Magyarországi boszorkányperek, 265-267; for Kata Szabó see ibid., 282-283; HBmL, IV. A. 1018/d 1, 33, 368; Bessenyei, A magyarországi boszorkányság, I. 368-371; for Mrs. András Bartha see Komáromy, Magyarországi boszorkányperek, 354-363; HBmL, IV. A. 1018/g 25. No. 2; Bessenyei, A magyarországi boszorkányság, I. 389-400.

74. Komáromy, Magyarországi boszorkányperek, 354-363; HBmL, IV. A. 1018/g 25. No. 2; Bessenyei, A magyarországi boszorkányság, I. 389-400.

75. HBmL, IV.A. 1011/t: Censuses, vol. 3: Censuses by streets, 1728 and 1730 .

76. For Mrs. Mihály Jóna see Komáromy, Magyarországi boszorkányperek, 428-429; HBmL, IV. A. 1018/g 25. No. 7; Bessenyei, A magyarországi boszorkányság, I. 401-417; for Mrs. András Nagy see HBmL, IV. A. 1018/g 25. No. 8; Bessenyei, A magyarországi boszorkányság, I. 422-428; for Mrs. András Vezendi see Komáromy, Magyarországi boszorkányperek, 430; HBmL, IV. A. 1018/g 25. No. 9; Bessenyei, A magyarországi boszorkányság, I. 417-422; for Mrs. Péter Kovács see HBmL, IV. A. 1018/g 25. No 8; for Mrs. János Szentesi see HBmL, IV. A. $1018 / \mathrm{g} 25$. No 8 .

77. Komáromy, Magyarországi boszorkányperek, 284.

78. Ibid., 430; HBmL, IV. A. 1018/g 25. No. 9; Bessenyei, A magyarországi boszorkányság, I. 417-422.

79. HBmL, IV. A. $1018 /$ g 25. No. 8; Bessenyei, A magyarországi boszorkányság, I. 422-428.

80. István Szücs, Szabad királyi Debrecen város történelme I-III. [The history of the free royal city Debrecen] (Debrecen: Városi Nyomda, 1871), III. 767.

81. HBmL, IV.A. 1011/a, vol. 41, 84-85: 24 March 1746.

82. HBmL, IV.A. 1018/d, dossier 1: 12 December 1727.

83. HBmL, IV.A. 1018/d, dossier 1: December 1727.

84. Komáromy, Magyarországi boszorkányperek, 428-429; HBmL, IV. A. 1018/g 25. No. 7; Bessenyei, A magyarországi boszorkányság, I. $401-417$.

85. Norbert Duka Zólyomi, 'Orvosképzés a nagyszombati egyetem orvosi karán' [Physician formation on the medical faculty of the Nagyszombat university], Orvostörténeti Közlemények, 51-53 (1969), 35-43; Árpád Fazekas, ‘A bábaellátás története Szabolcs-Szatmár megyében’ [Midwife training in Szabolcs-Szatmár county], Orvostörténeti Közlemények, 75-76 (1975), 137.

86. Béla Takács, 'A debreceni sebgyógyító céh története' [The history of the chirurgeon guild in Debrecen], A debreceni Déri Múzeum Évkönyve, (1981), 131-148; for the charter of the guild confirmed on 26 January 1736 by Emperor Charles III see HBmL, IX. 5.1. 
87. Lajos Szodoray, 'Debreceni orvosok, gyógyítók és kórházak a XVIIXVIII. században' [Physicians, healers and hospitals in Debrecen in the 17th and 18th centuries], Orvostörténeti Közlemények, 18 (1960), 132-133; Ferenc Benkő, 'Debrecen gyógyszertárai a XVIII. században' [The pharmacies in Debrecen in the 18th c.], A debreceni Déri Múzeum Évkönyve, LVII (1976), 89-90.

88. Szodoray, 'Debreceni orvosok', 133-134.

89. János Halmai, 'Gyógyszertár az “Arany Egyszarvúhoz” Debrecenben' [Pharmacy dedicated to the "Golden Unicorn" in Debrecen], Orvostörténeti Közlemények, 5 (1957), 175-178; id., 'Gyógyszerészeti instrukciók a XVIII. századból' [Pharmaceutical instructions from the 18th century], Orvostörténeti Közlemények, 10-11 (1957), 85.

90. Szodoray, 'Debreceni orvosok', 142.

91. For the rules and regulations of the guild confirmed on 26 January 1736 by Emperor Charles III see HBmL, IX. 5.1, articuli XVIII. and XXVI.

92. Gyula Jáki, 'Sebészvizsga a XVIII. században' [Surgeon examination in the 18th century], Orvostörténeti Közlemények, 1 (1955), 8-9.

93. Cited in Jáki, 'Sebészvizsga', 9-19, 21-22 (my emphasis: I. Sz. K.).

94. HBmL, IV.A. 1011/a, vol. 23: 17 March 1696.

95. Zoltánné Mervó, 'Debrecen város egészségügye a levéltári adatok tükrében' [Public health in Debrecen according to archival data], A HajdúBihar megyei Levéltár Évkönyve, 12 (1985), 111-112.

96. HBmL, IV. A. 1011/a 40, 1016; Bessenyei, A magyarországi boszorkányság, I. 445.

97. HBmL, IV. A. $1011 /$ a 38, 245.

98. Ibid., $1011 /$ a 38, 432.

99. Ibid., $1011 / \mathrm{a} 41,367$.

100. Ibid., $1011 / \mathrm{a} 42,2$.

101. Ibid., 1011/a 42, 182-183; Bessenyei, A magyarországi boszorkányság, I. 440 .

102. HBmL, IV. A. $1011 /$ a $40,435$.

103. HBmL, IV. A. $1011 /$ a 35, 665; Bessenyei, A magyarországi boszorkányság, I. 431-432; HBmL, IV. A. 1011/a 36, 248; Bessenyei, A magyarországi boszorkányság, I. 432.

104. HBmL, IV. A. 1011/a 37, 88; Bessenyei, A magyarországi boszorkányság, I. 432.

105. HBmL, IV.A. $1011 / \mathrm{a}$, vol. $41,163$.

106. HBmL, IV. A. $1011 /$ a 43, 418-419; Bessenyei, A magyarországi boszorkányság, I. 450-451.

107. Gyula Varga, Egy falu az országban. Kismarja életrajza a felszabadulásig [A village in the country. The biography of Kismarja until the Liberation] (Debrecen, 1978), 142. 
108. Gyula Varga (ed.), Berettyóniffalu története [The history of Berettyóújfalu] (Berettyóújfalu: Városi Tanács, 1981), 208.

109. Gyula Molnár 'Egy XVIII. századi gyógykovács-könyv receptjei' [The prescriptions of an 18th century healer's book], Ethnographia, LXXV (1964), 458ff.; id., 'Konyár egészségügyi körülményei a XVIII-XIX. században' [Health conditions in Konyár in the 18th and 19th century], Orvostörténeti Közlemények, 45 (1968), 88.

110. Imre Haász, 'Boszorkánypörök Debrecenben' [Witch trials in Debrecen], Debreceni Szemle, III (5) (1929), 1, 228.

111. István Rácz, 'A cívis fogalma' [The notion of the cívis], $A$ debreceni Déri Múzeum Évkönyve 1985 (1986), 79-88; István Balogh, Cívisek társadalma [The cívis society] (Debrecen: Misztótfalusi, 1946), 29-30.

112. Rácz, 'A cívis fogalma', 96; Balogh, Cívisek, 29-30.

113. For examples from the 16th century, see HBmLf, 7 (1983), 23, 27, 29, 35; 10 (1985), 12, 13, 43-44; 15 (1986), 9, 21; Gábor Herpay, A debreczeni református ispotály története 1529-1929 [The history of the Calvinist hospice in Debrecen] (Debrecen, 1929), 121.

114. Zoltán Kováts, 'A népesedési viszonyok' [Demography], in István Rácz (ed.), Debrecen története 2 (1693-1849) (Debrecen: Debrecen Megyei Városi Tanács Vb, 1981), 15.

115. Balogh, Cívisek; Gyula Varga, 'Ipari termelés—a társadalom ipari rétegei' [Industrial production-the industrial strata in the society], in István Rácz (ed.), Debrecen története 2 (1693-1849) (Debrecen: Debrecen Megyei Városi Tanács Vb, 1981), 309-352; Sándor Gyimesi, 'Kereskedelem, közlekedés, hitelszervezet és társadalmi problémái' [Commerce, traffic, credit and social problems], in Rácz, Debrecen története 2, 353-358.

116. HBmL, IV.A. 1011/a, vol. 23: 15 January and 20 May 1696.

117. Matricula Civium Liberae ac Regiae Civitatis Debreczinensis 1709-1724: Formula Juramenti Civium Incorporandorum, February 1707: OL (National Archives of Hungary), Collection of microfilms, roll 3459. 112.

118. Herpay, A debreczeni református, 9-10; Mervó, 'Debrecen város', 109.

119. Herpay, A debreczeni református, 71.

120. Ibid., 44.

121. HBmL, IV.A. 1011/a, vol. 23, 276.

122. Herpay, A debreczeni református, 92,73 .

123. HBmL, IV.A. 1011/a, vol. 30, 155: 2 June 1720.

124. HBmL, IV.A. 1011/a, vol. 23: 23 and 28 May 1695; vol. 35, 584: 26 June 1740; vol. 35, 593: 10 July 1740.

125. HBmL, IV.A. 1011/a, vol. 23: 31 May 1696.

126. Thomas, Religion; Macfarlane, Witchcraft in Tudor. 
127. Komáromy, Magyarországi boszorkányperek, 170-3.

128. Ibid., 286.

129. Komáromy, Magyarországi boszorkányperek, 282-283; HBmL, IV. A. 1018/d 1. 33, 368; Bessenyei, A magyarországi boszorkányság, I. 368-371.

130. Schram, Magyarországi boszorkányperek, 73-78; Komáromy, Magyarországi boszorkányperek, 268-269; HBmL, IV. A. 6/b. 2 No. 48.; Bessenyei, A magyarországi boszorkányság, I. 136-137.

131. Schram, Magyarországi boszorkányperek, I. 78-80; Komáromy, Magyarországi boszorkányperek, 271.

132. HBmL, IV. A. 6. b. 1. No. 61; Schram, Magyarországi boszorkányperek, I. 124; Bessenyei, A magyarországi boszorkányság, I. 448.

133. Komáromy, Magyarországi boszorkányperek, 511-514.

134. Ibid., 218-222.

135. Schram, Magyarországi boszorkányperek, I. 71-73.

136. Komáromy, Magyarországi boszorkányperek, 303-306.

137. Schram, Magyarországi boszorkányperek, I. 112.

138. Komáromy, Magyarországi boszorkányperek, 368-374.

139. Béla Molnár, 'Adalékok a komádi tanyák történetéhez és a tanyai lakosság életmódjának mai alakulásához' [Data on the ranches of Komád and the present way of life of the ranch inhabitants], Ethnographia, LXCIII (1952), 371-407.

140. Schram, Magyarországi boszorkányperek, I. 67-71.

141. Komáromy, Magyarországi boszorkányperek, 100.

142. Ibid., 101.

143. Midelfort, Witch Hunting, 187-190.

144. Schram, Magyarországi boszorkányperek, I. 113-115.

145. HBmL, IV. A. 6 b. 1. No. 88, 89; Bessenyei, A magyarországi boszorkányság, I. 157-160.

146. István Szendrey, Egy alföldi uradalom a török hódoltság után [A manor from the Hungarian Plain after the Turkish occupation] (Budapest: Akadémiai, 1968), 15-19; István Györffy, A hajdúk eredete [The origin of the hajdú] (Offprint), (Hajdúnánás: Hajdúnánási Újság, 1938).

147. Károly Mezösi, Bihar vármegye a török uralom megszünése idejében (1692) [Bihar county around the end of the Turkish rule] (Budapest: Magyar Történettudományi Intézet, 1943), 210-211.

148. Ibid., 212-213.

149. Szendrey, Egy alföldi, 38-46.

150. Ibid., 20.

151. Ibid., Szendrey s.d.

152. Szendrey, Egy alföldi, 36.

153. Ibid., 66-70. 
154. Ibid., 66-70.

155. Schram, Magyarországi boszorkányperek, I. 44-47; Szendrey s.d., 13.

156. For Mrs. György Borbély see Schram, Magyarországi boszorkányperek, I. 55-57; Komáromy, Magyarországi boszorkányperek, 277; for Mrs. Péter Juhos Kis see Schram, Magyarországi boszorkányperek, I. 55-56; Komáromy, Magyarországi boszorkányperek, 277; see also Szendrey s.d., 18.

157. Komáromy, Magyarországi boszorkányperek, 303-306; Imre Dankó (ed.), Bagosi krónika [Chronicle of Bagos] (Hajdúbagos, 1975), 18.

158. Szendrey s.d., 13.

159. Ibid.

160. Schram, Magyarországi boszorkányperek, 82.

161. Ibid., 84-85.

162. Ibid., 87.

163. Gábor Klaniczay, 'Hungary: The Accusations and the Universe of Popular Magic', in Bengt Ankarloo and Gustav Henningsen (eds), Early Modern European Witchcraft. Centres and Peripheries (Oxford: Clarendon, 1990), 255.

164. Éva Pócs, 'Gondolatok a magyarországi boszorkányperek néprajzi vizsgálatához' [Thoughts on the ethnographic examination of Hungarian witch trials], Ethnographia, XCIV (1983), 134-46; ead., 'Malefíciumnarratívok-konfliktusok-boszorkánytípusok' (Sopron vármegye 1529-1768.)' [Maleficium narratives-conflicts-witch-types: Sopron county], Népi Kultúra-Népi Társadalom, XVIII (1995), 9-66.

165. Demos, Entertaining Satan. 


\section{Palgrave Historical Studies in Witchcraft and Magic}

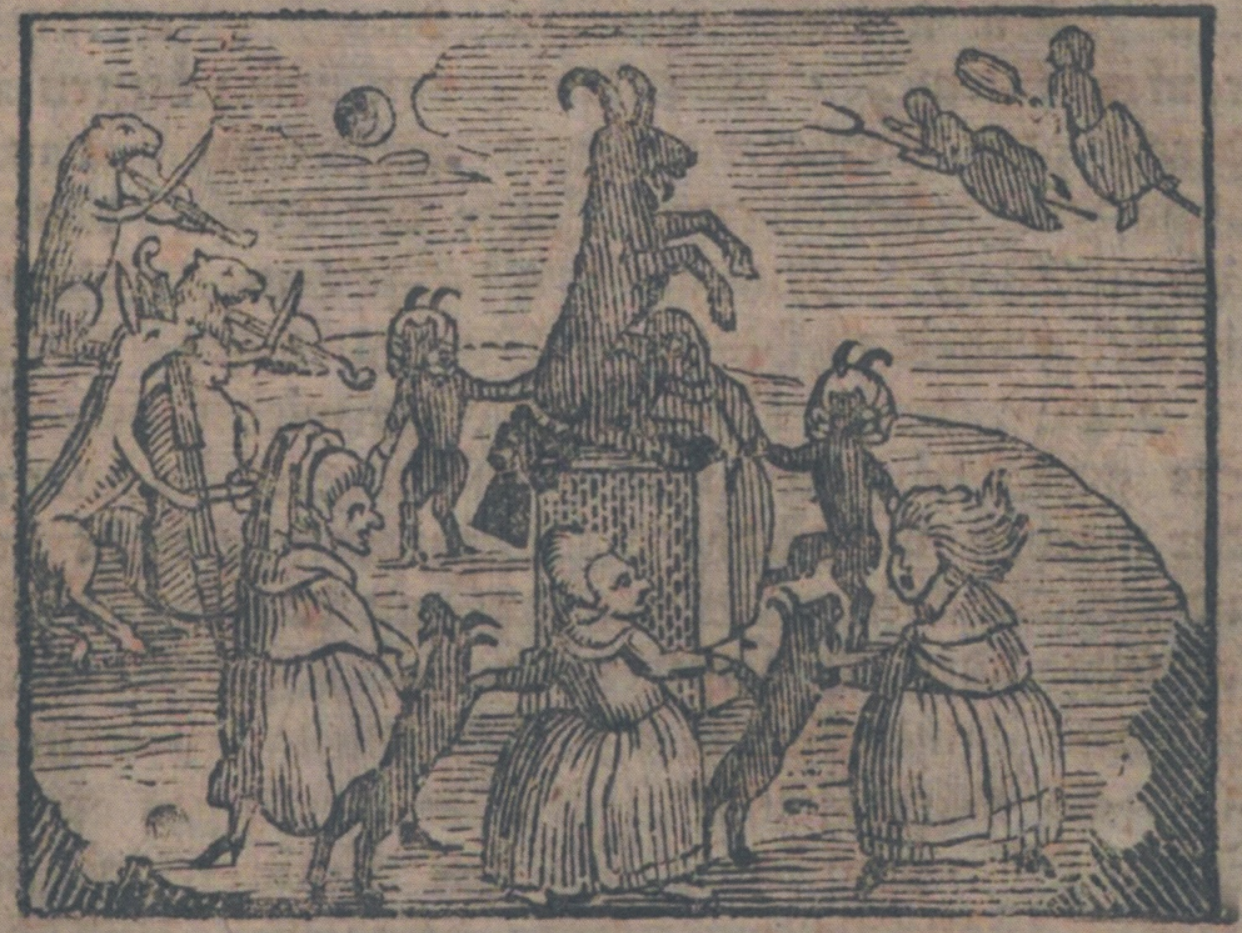

\section{Witchcraft and Demonology in Hungary and Transylvania}

Edited by

Gábor Klaniczay and Éva Pócs

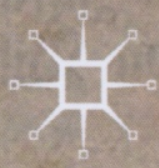


This book provides a selection of studies on witchcraft and demonology by those involved in an interdisciplinary research group begun in Hungary thirty years ago. They examine urban and rural witchcraft conflicts from early modern times to the present, from a region hitherto rarely taken into consideration in witchcraft research. Special attention is given to healers, midwives, and cunning folk, including archaic sorcerer figures such as the táltos; whose ambivalent role is analysed in social, legal, medical and religious contexts. This volume examines how waves of persecution emerged and declined, and how witchcraft was decriminalised. Fascinating case-studies on vindictive witch-hunters, quarrelling neighbours, rivalling midwives, cunning shepherds, weather magician impostors, and exorcist Franciscan friars provide a colourful picture of Hungarian and Transylvanian folk beliefs and mythologies, as well as insights into historical and contemporary issues.

Gábor Klaniczay is Professor of Medieval Studies at the Central European University, Budapest, Hungary. His research interests are in the history of medieval and early modern sainthood and witchcraft. His previous books include The Uses of Supernatural Power (1990) and Holy Rulers and Blessed Princesses (2002). He coedited with Éva Pócs a three volume series, 'Demons, Spirits Witches' $(2005,2006,2008)$.

Éva Pócs is Professor Emeritus at the Hungarian Academy of Sciences, Pécs, Hungary. Her main areas of research are folk religion and folk beliefs, and witchcraft and demonology. Her previous publications include Fairies and Witches at the Boundary of South-Eastern and Central Europe (1989) and Between the Living and the Dead: A Perspective on Witches and Seers in the Early Modern Age (1998).

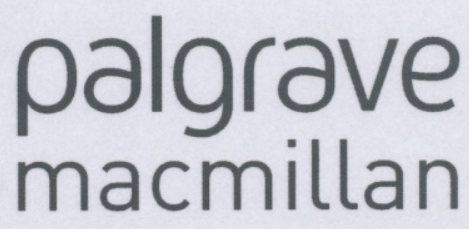

I SBN $978-3-319-54755-8$

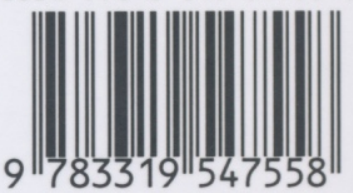

www.palgrave.com 
Gábor Klaniczay · Éva Pócs

Editors

Witchcraft and

Demonology in

Hungary and

Transylvania

\section{palgrave macmillan}


Editors

Gábor Klaniczay

Central European University

Budapest, Hungary
Éva Pócs

Hungarian Academy of Sciences

Pécs, Hungary

Palgrave Historical Studies in Witchcraft and Magic

ISBN 978-3-319-54755-8

DOI $10.1007 / 978-3-319-54756-5$

ISBN 978-3-319-54756-5 (eBook)

\section{Library of Congress Control Number: 2017944560}

(C) The Editor(s) (if applicable) and the Author(s) 2017

This work is subject to copyright. All rights are solely and exclusively licensed by the Publisher, whether the whole or part of the material is concerned, specifically the rights of translation, reprinting, reuse of illustrations, recitation, broadcasting, reproduction on microfilms or in any other physical way, and transmission or information storage and retrieval, electronic adaptation, computer software, or by similar or dissimilar methodology now known or hereafter developed.

The use of general descriptive names, registered names, trademarks, service marks, etc. in this publication does not imply, even in the absence of a specific statement, that such names are exempt from the relevant protective laws and regulations and therefore free for general use.

The publisher, the authors and the editors are safe to assume that the advice and information in this book are believed to be true and accurate at the date of publication. Neither the publisher nor the authors or the editors give a warranty, express or implied, with respect to the material contained herein or for any errors or omissions that may have been made. The publisher remains neutral with regard to jurisdictional claims in published maps and institutional affiliations.

Cover image: Becker, Rudolf Zacharias: Noth- und Hülfsbüchlein für den Landmann : welches lehret, wie man vergnügt leben und mit Ehren reich werden könne, desgleichen wenn man Leute findet, welche erfroren, ersoffen, erstickt oder erhenkt [...]. In Leipzig: verlegt bey G.J. Göschen [1785]. Source: Zentralbibliothek Zürich

Printed on acid-free paper

This Palgrave Macmillan imprint is published by Springer Nature

The registered company is Springer International Publishing AG

The registered company address is: Gewerbestrasse 11, 6330 Cham, Switzerland 
Translated from the Hungarian by Anna Klaniczay Style edited by Andrew Rouse Index prepared by Judit Kis-Halas 


\section{Contents}

Introduction

Gábor Klaniczay and Éva Pócs

The Social Background of Witchcraft Accusations in Early Modern Debrecen and Bihar

County

Ildikó Sz. Kristóf

Witchcraft, Greed and Revenge: The Prosecutor Activity of György Igyártó and the Witch Trials of Kolozsvár in the 1580s

László Pakó

Healers in Hungarian Witch Trials

Gábor Klaniczay

Divinatio Diabolica and Superstitious Medicine:

Healers, Seers and Diviners in the Changing

Discourse of Witchcraft in Early Modern Nagybánya

Judit Kis-Halas

Shamanism or Witchcraft? The Táltos Before the Tribunals Éva Pócs 
The Decriminalization of $\dot{M}$ agic and the Fight Against Superstition in Hungary and Transylvania, 1740-1848 Pèter Tóth G.

Demonology and Catholic Enlightenment in

Eighteenth-Century Hungary

Dániel Bárth

Talking Through Witchcraft-on the Bewitchment Discourse of a Village Community Ágnes Hesz

Index 